\title{
MECHANISMS OF CYTOTOXICITY OF THREE NEW CATECHOLS AND ONE NAPHTHALENEDIOL
}

\author{
by \\ ALEXANDRU CHICHIRAU, M.Sc. \\ A thesis submitted to the Faculty of Graduate Studies and Reesearch \\ in partial fulfillment of the requirements for the degree of \\ Master of Science \\ Department of Chemistry
}

\section{CARLETON UNIVERSITY}

Ottawa, Ontario, Canada

January 2008

Ccopyright

2008, Alexandru Chichirau 


$\begin{array}{ll}\begin{array}{l}\text { Library and } \\ \text { Archives Canada }\end{array} & \begin{array}{l}\text { Bibliothèque et } \\ \text { Archives Canada }\end{array} \\ \begin{array}{l}\text { Published Heritage } \\ \text { Branch }\end{array} & \begin{array}{l}\text { Direction du } \\ \text { Patrimoine de l'édition }\end{array} \\ \begin{array}{l}\text { 395 Wellington Street } \\ \text { Ottawa ON K1A 0N4 } \\ \text { Canada }\end{array} & \begin{array}{l}\text { 395, rue Wellington } \\ \text { Ottawa ON K1A 0N4 } \\ \text { Canada }\end{array}\end{array}$

Your file Votre référence ISBN: 978-0-494-40655-7

Our file Notre référence

ISBN: 978-0-494-40655-7

NOTICE:

The author has granted a nonexclusive license allowing Library and Archives Canada to reproduce, publish, archive, preserve, conserve, communicate to the public by telecommunication or on the Internet, loan, distribute and sell theses worldwide, for commercial or noncommercial purposes, in microform, paper, electronic and/or any other formats.

The author retains copyright ownership and moral rights in this thesis. Neither the thesis nor substantial extracts from it may be printed or otherwise reproduced without the author's permission.
AVIS:

L'auteur a accordé une licence non exclusive permettant à la Bibliothèque et Archives Canada de reproduire, publier, archiver, sauvegarder, conserver, transmettre au public par télécommunication ou par l'Internet, prêter, distribuer et vendre des thèses partout dans le monde, à des fins commerciales ou autres, sur support microforme, papier, électronique et/ou autres formats.

L'auteur conserve la propriété du droit d'auteur et des droits moraux qui protège cette thèse. $\mathrm{Ni}$ la thèse ni des extraits substantiels de celle-ci ne doivent être imprimés ou autrement reproduits sans son autorisation.
In compliance with the Canadian Privacy Act some supporting forms may have been removed from this thesis.

While these forms may be included in the document page count, their removal does not represent any loss of content from the thesis.
Conformément à la loi canadienne sur la protection de la vie privée, quelques formulaires secondaires ont été enlevés de cette thèse.

Bien que ces formulaires aient inclus dans la pagination, il n'y aura aucun contenu manquant.

\section{Canada}




\section{ABSTRACT}

Catechols (ortho-hydroxyphenols) are widely distributed in nature, and can also be produced in animals by biosynthetic pathways. Catechols found in foods play important roles as antioxidants. In this thesis several synthetic catechols, a naphthalenediol and the known compounds menadiol/menadione will be discussed. Inside cells catechols can be metabolized to electrophilic quinones, which cause cell death by several mechanisms. Determining which mechanism of toxicity is dominant in adrenal pheochromocytoma (PC12) cells is the focus of this work

Several assays were used to monitor toxic effects on the cells. These included use of catalase as a probe of peroxide presence, monitoring of GSH levels, and measurement of the initial rates of peroxide and quinone production. These observations showed that extracellular autoxidation is the main mechanism of toxicity for the synthetic catechols. The naphthalenediol studied showed a different mechanism, the induction of lipid peroxidation. Both menadiol and menadione were shown to severely deplete GSH. Thus, small variations in the diol structure led to significant differences in the cytotoxicity of this family of compounds. 


\section{ACKNOWLEDGEMENTS}

Firstly and foremost I have to thank my supervisor, Dr. James Wright, for teaching me how to always think and plan ahead, to come up with hypothesis and to discuss results and ideas. He is always supportive and helpful, kind and generous. By seeking the real answer and the meaning and usefulness of our work, he pushed me to become a better and true researcher. I will always be inspired by his professionalism, attention to details, hard work and patience.

For always being there to answer my questions, to talk about science and work, to advise on research and writing, to help with ideas and solution, to constantly support and mentor, I am nothing but deeply thankful to my cosupervisor, Dr. William Willmore.

For being good colleagues and sharing the graduate student life with me, many thanks to Mihaela Flueraru, Leonid Chepelev, Dr. Hooman Shadnia, Remmick So, Eman Ahmed -Muhsin from the Wright's lab and Angie, Mohamed, Jacques and Ahmed from Willmore's lab.

All my work could not have been completed without the help of Dr. Steffany Bennett from the University of Ottawa for providing the PC 12-AC cells and Dr. Tony Durst and his hard working group (Dr. Helmi Hussain and Martin Charron) for synthesizing the new compounds.

Sincere thanks for the all the people of QBM Cell Science, Ottawa, in particular Queade and Kenji, for just being the best bunch of people to work with. 
I can't finish without thanking from the bottom of my heart to my mom who always supported me and even far away from me she was always near me and in my heart and life. Thanks to Clark for supporting me during my student life and understanding the duties of a grad student without understanding the science behind it.

Thank you all again and my deepest gratitude for your help! 


\section{TABLE OF CONTENT}

Title page

Copyright form ii

Abstract iii

Acknowledgments

Table of content vi

List of abbreviations viii

List of tables $\quad$ xi

List of figures . $\quad$ xii

Chapter 1 - INTRODUCTION 1

1.1. Phenolic antioxidants as a class 2

1.2. Synthetic phenols 4

1.3. Effect of substituents 5

$\begin{array}{ll}\text { 1.4. Naturally occurring catechols } & 6\end{array}$

1.5. Catechols as metabolites of benzene and phenol 7

$\begin{array}{ll}\text { 1.6. Catechols react fast with DPPH radical } & 7\end{array}$

1.7. Catechols as prooxidants 9

1.8. Mechanisms of diol toxicity 10

1.8.1. Reactions of quinones with intracellular thiols 12

1.8.2. Reactions of quinones with DNA bases 13

1.8.3. ROS generation by quinones through redox cycling 15

1.9. Effects of diols on intracellular GSH content 17

$\begin{array}{lr}\text { 1.10. Menadione } & 19\end{array}$ 
1.11. Hypothesis and aims

Chapter 2 - MATERIALS AND METHODS 25

2.1. Chemicals 26

2.2. Cell culture 26

2.3. Tested compounds 26

2.4. Text for toxicity - cell viability 29

2.5. Hydrogen peroxide (FOX- ferric oxidase) assay 30

2.6. Extracellular quinone assay 31

2.7. Glutathione assay 32

2.8. Protein determination 33

2.9. Statistics 34

Chapter 3 - RESULTS $\quad 35$

3.1. Cytotoxicity 36

3.2. Hydrogen peroxide production 39

3.3. Quinone quantification 43

3.4. GSH cellular content 44

3.5. Menadiol - Menadione 46

Chapter 4 - DISCUSSIONS $\quad 54$

4.1. Cytotoxicity - with and without catalase

4.2. Correlation between cytotoxicity and intracellular GSH levels 57

4.3. Cytotoxicity is correlated with hydrogen peroxide generation $\quad 59$

$\begin{array}{ll}\text { REFERENCES } & 67\end{array}$ 


\section{LIST OF ABBREVIATIONS}

$\gamma \mathrm{GCL}$ - $\gamma$-glutamyl-cystein ligase

$\gamma$ GCS - $\gamma$-glutamyl cystein synthese

2-OHE - 2-hydroxyestrone

4-OHE - 4-hydroxyestrone

4-OHEN- 4-hydroxyequilenin

4-OHEQ - 4-hydroxyequilin

ADP - adenosine diphosphate

ATP - adenosine triphosphate

BHA - tert-butyl-4-hydroxyanisole

BHT - 2,6-di-tert-butyl-p-cresol

BSO - buthionine sulfoximine

DA - diacetate

DMSO - dimethyl sulfoxide

DNA - deoxyribonucleic acid

DPND - 1,4-dipropyl-naphthalene-2,3-diol

DPPH - 1,1-diphenyl-2-picrylhydrazyl

DTNB - 5,5'-dithiobis(2-nitrobenzoic acid

$E_{50}$ - effective concentration that reduced viability of PC-12AC cells by $50 \%$ of controls

EDTA - ethylenediamine tetraacetic acid

EGCG - epigallocatechin gallate

ESR - electron spin resonance 
FOX-ferric oxidase

GR - glutathione reductase

GSH - glutathione, reduced form

GSSG - glutathione, oxidized

GS-SPr - glutathione-thiol protein disulfide

$\mathrm{H}_{2} \mathrm{O}_{2}$ - hydrogen peroxide

HAT - hydrogen-atom transfer

HBSS - Hank's balanced salt solution

HO' - hydroxyl radical

HRT - hormone replacement therapy

KP I - potassium phosphate buffer

L-DOPA - 3,4-dihydroxy-L-phenylalanine

LOO - lipid peroxyl radical

LOOH - lipid peroxide

MTT - 3-(3,5-dimethylthiazol-2-yl)-2,5-diphenyltatrazoliumbromide

NADH - nicotinamide adenine dinucleotide, reduced form

$\mathrm{NADP}^{+}$- nicotinamide adenine dinucleotide phsphate, oxidized form

NADPH - nicotinamide adenine dinucleotide phosphate, reduced form

NQO1 - NAD(P)H quinone oxidoreductase

$\mathrm{O}_{2}{ }^{--}$- superoxide radical anion

PAH - polycyclic aromatic hydrocarbons

PBS - phosphate buffer saline

PC12-AC - adherent line of rat adrenal pheochromocytoma cells

QSAR - quantitative structure - activity relationship

ROS - reactive oxygen species 
RPMI 1640 - Roswell Park Memorial Institute medium

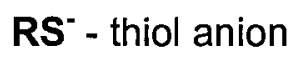

SEM - standard error of the mean

SOD - superoxide dismutase 


\section{LIST OF TABLES}

1.1. Classes of phenolic compounds in plants

2.1. $E C_{50}$ values for all the tested compounds in presence and absence of 50 catalase 


\section{LIST OF FIGURES}

1.1. Chemical structures of BHA and BHT 4

1.2. Generic structure of a flavonoid molecule 5

$\begin{array}{ll}\text { 1.3. Chemical structure of EGCG } & 6\end{array}$

1.4. Schematic representation of benzene metabolism 8

1.5. Two-step oxidation of catechol 11

1.6. Catechol as terminator of lipid peroxidation 11

1.7. Formation of superoxide radical anion by $\mathrm{H}$-atom transfer from 12 semiquinone

1.8. Electrophilic 1,4-addtion to 1,4-benzoquinone 13

1.9. Formation of unstable depurinating adducts from the reaction of 4- 14 hydroxyestrone-o-quinone with deoxyguanosine

1.10. Synthesis of Catechol-4- $\mathrm{N}_{7}$ Guanine and Catechol-4- $\mathrm{N}_{3}$ Adenine by reaction of Catechol quinone with 2'-Deoxyguanosine or Adenine

1.11. Generation of reactive oxygen species (ROS) by redox cycling

2.1. Chemical structures of $\mathrm{H} 1$ and $\mathrm{H} 1-\mathrm{DA}$

2.2. Chemical structures of $\mathrm{H} 2$ and $\mathrm{H} 2-\mathrm{DA}$

2.3. Chemical structures of $\mathrm{H} 4$ and $\mathrm{H} 4-\mathrm{DA}$

2.4. Chemical structures of DPND and DPND-DA

2.5. Chemical structures of Menadiol, Menadiol-DA and Menadione

3.1. Toxicity of H1-DA to PC12-AC cells in the presence and absence of added catalase 
3.2. Toxicity of H2-DA to PC12-AC cells in the presence and absence of catalase

3.3. Toxicity of H4-DA to PC12-AC cells in the presence and absence of catalase

3.4. Toxicity of DPND-DA to PC12-AC cells in the presence and absence of catalase

3.5. Extracellular hydrogen peroxide in the medium when PC12-AC cells were incubated with $100 \mu \mathrm{M}$ of each of the test compounds

3.6. Hydrogen peroxide time course for the autoxidation of $100 \mu \mathrm{M}$ of each of the tested componds in HBSS

3.7. Time course for the extracellular levels of quinones measured after incubating $100 \mu \mathrm{M}$ of each of the catechols with PC12-AC cells in HBSS

3.8. Total glutathione (GSH and GSSG) response curves to increasing 45 concentrations of tested compounds in their DA form

3.9. Menadiol-DA toxicity to PC12-AC after 24 hours of incubation at $37^{\circ} \mathrm{C}$ in the presence and absence of added catalase

3.10. Menadiol toxicity to PC12-AC. PC12-AC were incubated, with or without catalase

3.11. Toxicity of Menadione to PC12-AC in the presence and absence of catalase

3.12. Total glutathione response curves to treatment with different concentrations of menadiol for 3 and 24 hours at $37^{\circ} \mathrm{C}$.

3.13. Total glutathione (GSH and GSSG) response curves as function of menadione concentration for 3 and 24 hour incubations at $37^{\circ} \mathrm{C}$. 
4.1. Dihydroxy, semiquinone and quinone forms of 1,2-naphthalenediol

4.2. Dihydroxy, semiquinone and quinone forms of 1,4-naphthalenediol 62

4.3. Dihydroxy, semiquinone and quinone forms of 2,3-naphthalenediol 63 
Chapter 1

INTRODUCTION 


\subsection{Phenolic antioxidants as a class}

During normal physiological processes reactive oxygen species (ROS) are constantly produced but the antioxidant defence mechanisms of the organism remove and annihilate them (Halliwell, 1992). When there is an imbalance between the ROS levels and the native antioxidant defence mechanisms, a state of oxidative stress occurs that can lead to damage at the cellular membrane level and to modification of the intracellular molecules (ElHabit, 2000)

Phenolic compounds are biosynthesised in plants and vegetables as secondary metabolites from the pentose phosphate, polyketide and shikimic acid pathways. They play a wide range of physiological roles such as antioxidant, anti-allergenic, anti-atherogenic, anti-inflammatory, anti-microbial, cardioprotective, anti-thrombotic etc (Manach, 2005, Puupponen-Pimaja, 2001).

The consumption of high levels of fruits and vegetables are associated with health benefits (Parr, 2000). These beneficial effects of the phenolic compounds were associated with their antioxidant activity (Heim, 2002).

Structurally, phenolic compounds are aromatic rings bearing one of more hydroxyl groups and vary in complexity from simple molecules (catechol) to polymerized compounds (eg. tannins) (Bravo, 1998). 
Table 1.1. Classes of phenolic compounds in plants (Harborne, 1999)

\begin{tabular}{|l|c|}
\hline Class & Structure \\
\hline Simple phenolics, benzoquinones & $\mathrm{C}_{6}$ \\
\hline Hydroxybenzoic acids & $\mathrm{C}_{6}-\mathrm{C}_{1}$ \\
\hline Acetophenones, phenylacetic acids & $\mathrm{C}_{6}-\mathrm{C}_{2}$ \\
\hline $\begin{array}{l}\text { Hydroxycinnamic acids, phenylpropanoids (coumarins, } \\
\text { chromones etc) }\end{array}$ & $\mathrm{C}_{6}-\mathrm{C}_{3}$ \\
\hline Naphthoquinones & $\mathrm{C}_{6}-\mathrm{C}_{4}$ \\
\hline Xanthones & $\mathrm{C}_{6}-\mathrm{C}_{1}-\mathrm{C}_{6}$ \\
\hline Stilbenes, anthraquinones & $\mathrm{C}_{6}-\mathrm{C}_{2}-\mathrm{C}_{6}$ \\
\hline Flavonoids, Isoflavonoids & $\mathrm{C}_{6}-\mathrm{C}_{3}-\mathrm{C}_{6}$ \\
\hline Lignans & $\left(\mathrm{C}_{6}-\mathrm{C}_{3}\right)_{2}$ \\
\hline Biflavonoids & $\left(\mathrm{C}_{6}-\mathrm{C}_{3}-\mathrm{C}_{6}\right)_{2}$ \\
\hline Lignins & $\left(\mathrm{C}_{6}-\mathrm{C}_{3}\right)_{\mathrm{n}}$ \\
\hline Condensed tannins & $\left(\mathrm{C}_{6}-\mathrm{C}_{3}-\mathrm{C}_{6}\right)_{\mathrm{n}}$ \\
\hline
\end{tabular}

The potency of an antioxidant is dictated by:

- its reactivity as a hydrogen- or electron-donating compound (related to the reduction potential)

- the fate of the radical formed as a result of the reaction between the phenolic compound and the oxidant species (related to the ability of the radical to stabilize and delocalize the unpaired electron)

- its reactivity with other antioxidants (possibility to regenerate)

- its potential to chelate transition metals (Rice-Evans, 1997).

The efficacy of an antioxidant also depends on which of the reactive oxygen or nitrogen species scavenged, on the location and generation of the 
oxidative stress and on the accessibility of the antioxidant to the site of damage. For instance, a water-soluble compound will be less active in protecting against oxidative stress that occurs in lipid particles or cell membranes (Morton, 2000).

\subsection{Synthetic phenols}

Synthetic antioxidants such as butylated hydroxyanisole (BHA), butylated hydroxytoluene (BHT) and tert-butylhydroquinone (TBHQ) have been in use for years in a wide variety of products, including foods. Over the years concerns over their toxicity effects and safety use were raised (Wanasundara, 1998). Intensive research and study of the natural antioxidants focused particularly on phenolic compounds such as flavonoids and hydroxycinnamic acids. The synthetic structures studied and proposed for antioxidant uses are usually substituted phenolic compounds (Martinez, 2002).
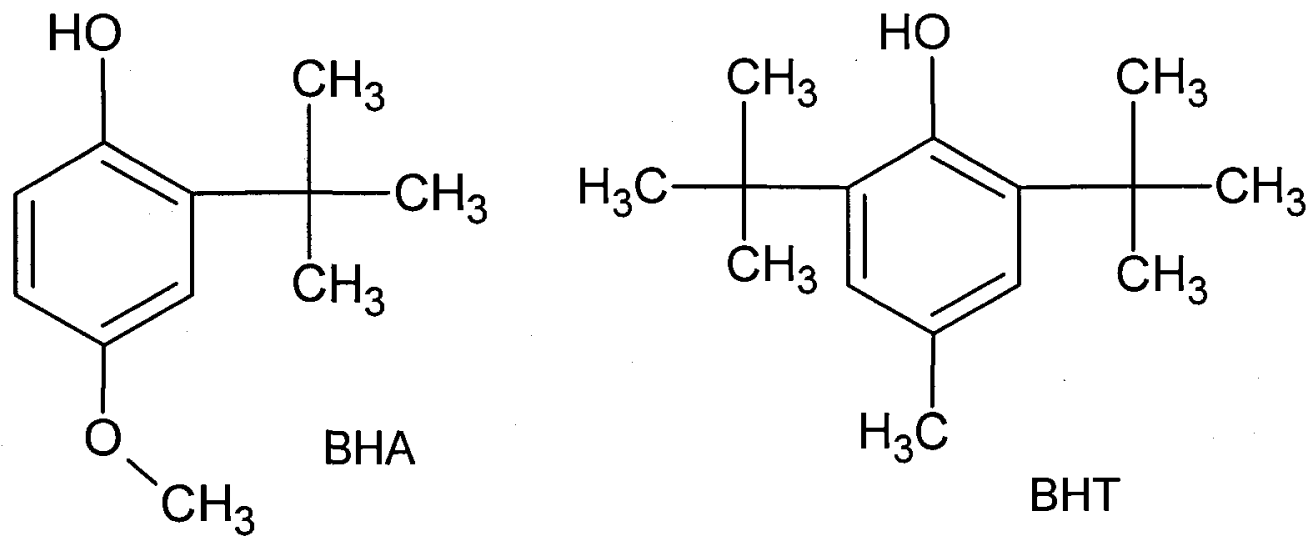

Figure 1.1. Chemical structures of BHA and BHT 


\subsection{Effect of substituents}

The antioxidant activity of the phenols was the object of many structure-activity studies, all of which focused on the aromatic $\mathrm{OH}$ groups. It was even proposed that the potency of a given flavonoid is proportional to the number of hydroxyl groups (Cao, 1997).

In 2002, Heijnen characterized the influence of substituents on the antioxidant activity of phenols. They tested the effect of a second $\mathrm{OH}$ group and recorded higher lipid peroxidation inhibition when using the hydroxylated derivatives. The compounds substituted at the 2 (catechol) and 4 (hydroquinone) positions exhibited increased antioxidant activity compared to the phenol derivative hydroxylated at the 3 position (resorcinol). By altering the generic structure of a flavonoid molecule (figure 1.2.) they synthesized a series of flavones and correlated their antioxidant activity with their structure. The authors discovered that all synthetic compounds exhibited excellent lipid peroxidation protection capabilities, irrespective to the nature, position and number of the substituents at the $A C$ ring; as long as the $B$ ring contained a catechol moiety.

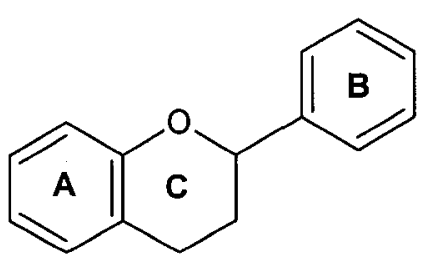

Figure 1.2. Generic structure of a flavonoid molecule

The increased antioxidant activity of the 0 - substituted phenols can be explained by the electron-donating nature of the substituent that can enhance 
the electron density at the oxygen of the phenol and by the strong internal $\mathrm{H}$ bond formed in the radical (Matsuura, 2000).

\subsection{Naturally occurring catechols}

Recently, the antioxidant properties of polyphenol compounds like catechins, flavonols, EGCG (epigallocatechin gallate) (Figure 1.3) have been intensively studied (Higdon, 2003 and Fraga, 2007). Their role as antioxidants in red wine as well as green and black tea is the focus of much media attention. The "French paradox" which refers to the extreme longevity and absence of heart disease in the south of France is explained by the consumption of red wine that contains polyphenols (De Lange, 2007).<smiles>O=C(O[C@@H]1Cc2c(O)cc(O)cc2O[C@@H]1c1cc(O)c(O)c(O)c1)c1cc(O)c(O)c(O)c1</smiles>

Figure 1.3. Chemical structure of EGCG

Catechols can be endogenously found in humans and mammals as neurotransmitters and their precursors - adrenaline, noradrenaline, dopamine and L-DOPA (L-3,4-dihydroxyphenulanaline) (Schweigert, 2001). The 
presence of phenols in the body can be due also to tobacco smoke that contains catechol, catechol quinones and polymerized catechols (Pryor, 1998).

\subsection{Catechols as metabolites of benzene and phenol}

The presence of catechols in the body is not only due to the direct uptake from different sources, but to the in vivo formation of this class of compounds from exogenous chemicals. It is well known (Schlosser, 1993 and Tsao, 1998) that catechols are formed during benzene metabolism (Figure 1.4). In this process, other $\mathrm{OH}$-bearing compounds are synthesized, such as phenols, hydroquinones and trihydroxybenzene.

\subsection{Catechols react fast with DPPH radical}

A commonly used method for the prediction of antioxidant activity is based on the scavenging of 2,2-diphenyl-1-picrylhydrazyl radical (DPPH) - a stable radical whose decrease in absorbance at $519 \mathrm{~nm}$ due to reaction with an antioxidant species is measured (Brighente, 2007).

Wang (2006) reported that quercitin, myricetin and fustin, all flavonoids that contain a catechol moiety in the B ring (position $3^{\prime}$ and $4^{\prime}$ ) have a much higher DPPH scavenging activity when compared to kaempherol $\left(4^{\prime}-\mathrm{OH}\right)$ and morin $\left(2^{\prime}, 4^{\prime}-\mathrm{di}-\mathrm{OH}\right)$. Their results suggest once again that in order to design a potent flavonoid antioxidant that will quickly react with the DPPH radical, the catechol moiety is a prerequisite. Other studies (Furusawa, 2005) support the conclusion that rapid reaction with DPPH correlates with high scavenging activity of the $3^{\prime}, 4^{\prime}$ - catechol motif. 


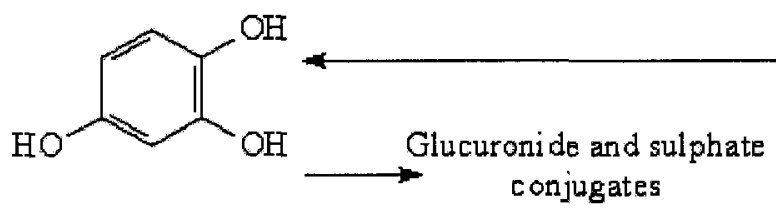

1,2,4-Trihy droxy benzene

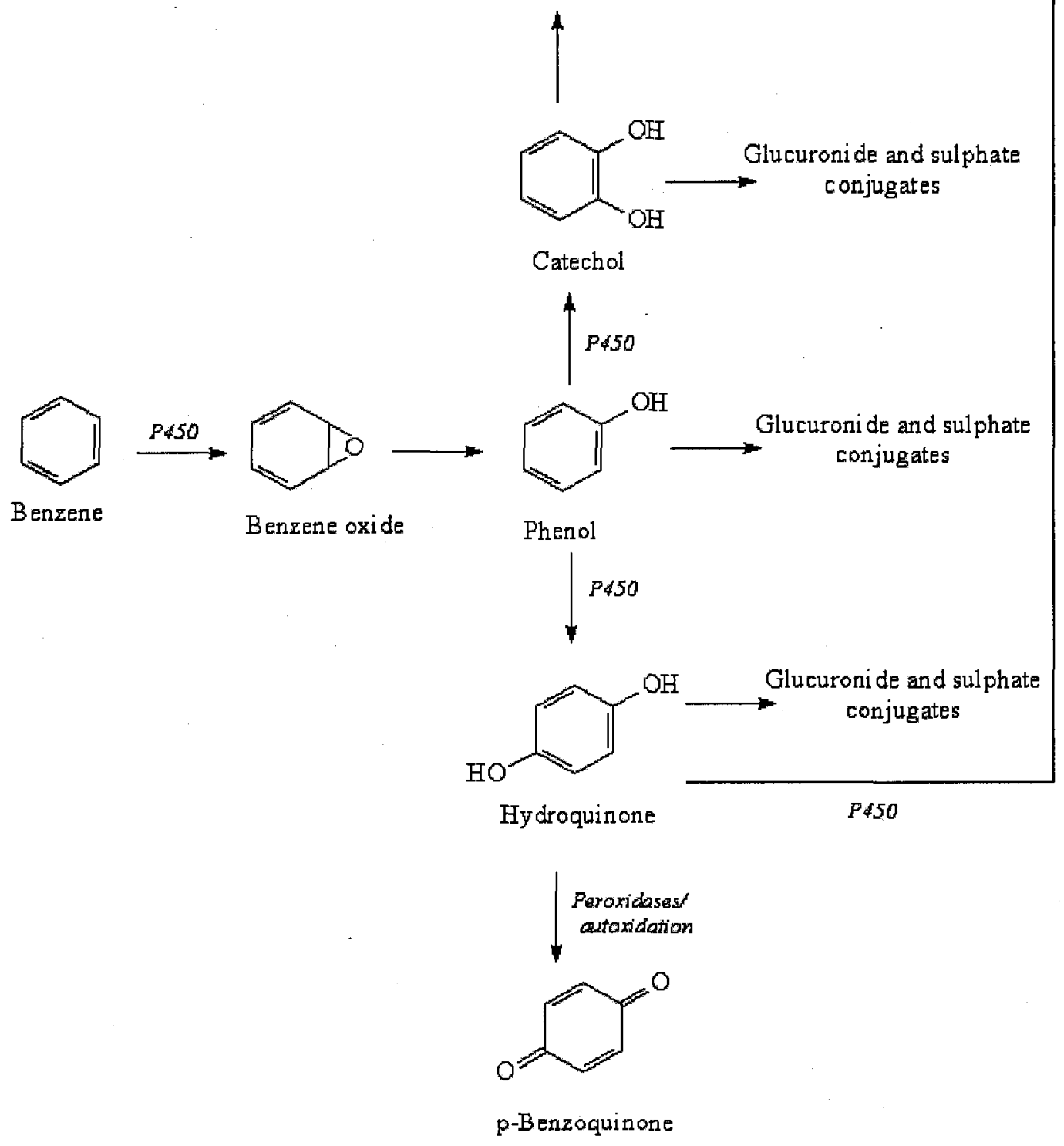

Figure 1.4. Schematic representation of benzene metabolism (Ross, 1996) 


\subsection{Catechols as prooxidants}

Despite numerous studies that have demonstrated the antioxidant abilities of catechols, there is an increasing amount of scientific literature that provides evidence for the prooxidant, cytotoxic effect of these compounds (Galati, 2004). The products of phenol oxidation - quinones - can arylate reduced glutathione and/or other cellular thiols, protein thiols, nucleophiles (e.g. DNA bases) (Boots, 2005). Catechols and other polyphenols autooxidize in aqueous media and can form toxic hydroxyl radicals if transition metals like iron or copper are present (Said Ahmad, 1992). They can also be substrates for enzymes like peroxidases and other metalloenzymes being converted to quinines; known prooxidants and/or alkylating agents (Moridani, 2001).

Moridani (2003) performed a QSAR study on the toxicity of phenols in rat hepatocytes and concluded that their cytotoxicity is a combination of mechanisms i.e. phenoxy radicals and/or phenol metabolism to quinones. Schweigert (2001) concluded that the mechanisms most cited to explain the cytotoxicity of the catecholic compounds are: generation of ROS by redox cycling, DNA damage by oxidative stress or arylation and protein damage by oxidation

or

thiol arylation.

In 2002, Boots et al. published their results on the anti and prooxidant activity of 4-methylcatechol. The authors confirmed that the catechol moiety is a potent antioxidant pharmacophore by preventing microsomal lipid peroxidation. At the same time they also reported the prooxidant activity of the quinone (4-methyl-ortho-benzoquinone) formed as a result of the catechol antioxidant action. The proposed mechanism of toxicity is protein sulphydryl arylation. Thus, despite the protection against lipid peroxidation promoted by 
the catechol-containing antioxidant, indirectly (by means of the quinone byproduct) they can also induce thiol arylation, which can stimulate lipid peroxidation by inactivating $\mathrm{GSH}$-dependent reductases, which are the native defence against lipid peroxidation.

The other mechanism of catechol toxicity (oxidative damage by hydrogen peroxide generation) on human erythrocytes was the focus of the research done by Bukowska in 2004. After performing a wide range of measurements ranging from reduced and total GSH levels, lipid peroxidation damage, glutathione reductase, catalase and superoxide dismutase activities, the authors concluded that is it the hydrogen peroxide production that plays the most important role in the toxicity process. At lower concentrations, catechol lowered the reduced glutathione levels, at moderate doses a decresed catalase activity was recorded while glutathione reductase and other enzyme are affected only at high doses.

\subsection{Mechanisms of diol toxicity}

In order to explain the toxicity of catechols, several mechanisms were proposed, all of them related to the quinone toxicity. The catechols by themselves are not toxic. The products of their metabolism, quinines, are responsible for the toxicity.

Once inside the cells, the catechols undergo a 2-step oxidation, with a quinone as final product (see Figure 1.5.).

Hydrogen Atom Transfer (HAT) Mechanism - the first step is HAT with the formation of a semiquinone, which is an unstable radical species. After a 
second $\mathrm{H}$-atom is transferred, the aromaticity in the benzene ring is lost and a quinone is formed.<smiles>O=C1C=CC=CC1=O</smiles>

Figure 1.5. Two-step oxidation of catechol

The first reaction can be beneficial for the cells, since the $\mathrm{H}$-atom can be transferred to a lipid peroxyl radical to stop the propagation of lipid peroxidation (Figure 1.6).

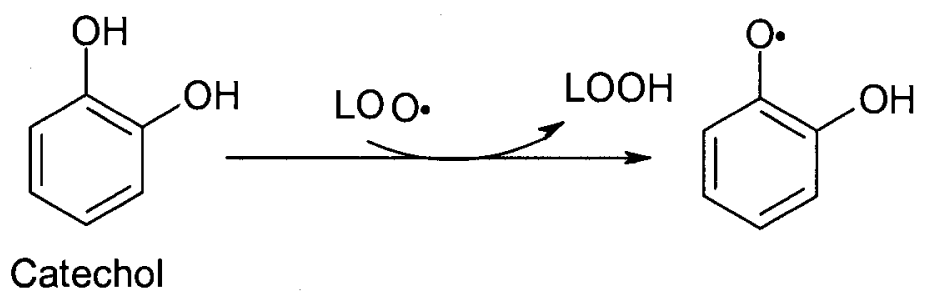

Figure 1.6. Catechol as terminator of lipid peroxidation

The second reaction, the formation of the quinone from semiquinone, can generate superoxide radical anion that is known to be cytotoxic (Benov, 2001) (Figure 1.7). Once the quinone is formed, it may have one of three different fates. 
<smiles>Oc1ccccc1O</smiles>

Semiquinone

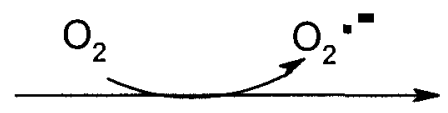$$
\text { (1) }
$$<smiles>O=C1C=CC=CC1=O</smiles>

Quinone

Figure 1.7. Formation of superoxide radical anion by $\mathrm{H}$-atom transfer from semiquinone

Quinones can: 1) act as electrophiles, directly modifying biomolecules such as glutathione and protein thiols, 2) act as electrophiles, attacking nucleophiles such as DNA bases and 3) catalyze the reduction of molecular oxygen via a redox cycle which generates superoxide and other reactive oxygen species (ROS) like hydrogen peroxide $\left(\mathrm{H}_{2} \mathrm{O}_{2}\right)$ and hydroxyl radical $(\mathrm{HO} \cdot)$.

\subsubsection{Reactions of quinones with intracellular thiols}

The presence of an $\alpha, \beta$-unsaturated carbonyl moiety allows quinones to participate in 1,4-addition reaction known as Michael addition. For instance, the toxicity of 1,4-benzoquinone has been exclusively attributed to its ability to undergo a Michael addition reaction (Tapper, 2000) (Figure 1.8) 


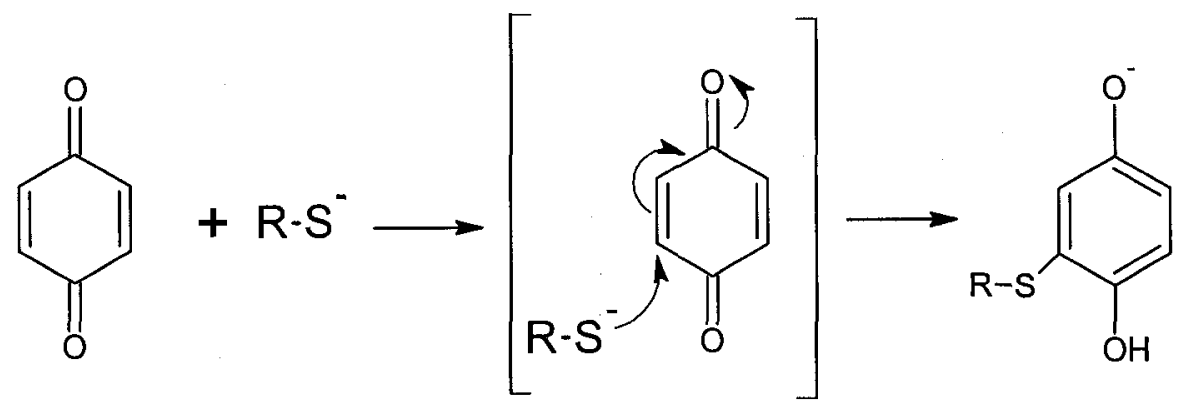

Figure 1.8. Electrophilic 1,4-addition to 1,4-benzoquinone

The mechanism of toxicity due to alkylation of critical cellular components by quinones was supported by studies involving substituted benzoquinones. In 1986 Rossi compared methyl-substituted 1,4benzoquinones and reported that their cytotoxicity was correlated with the ability to alkylate cellular thiols in isolated rat hepatocytes. Based on the $\mathrm{EC}_{50}$ values, the degree of methyl substitution. was inversely proportional to the cytotoxicity. The same trend was reported by Gant in 1988 when studying naphthoquinones and their ability to take part in 1,4-Michael addition reactions with cellular thiol components.

\subsubsection{Reactions of quinones with DNA bases}

Another target for the quinones to attack can be DNA with which quinones can form covalent adducts. There are two types of DNA adducts: stable ones that can only be removed through a repair mechanism and depurinating ones that are released from the DNA by destabilization of the glycosyl bond (Cavalieri, 2002). It had been proposed that the depurinating adducts formed by catechol-estrogen quinones reacting with DNA are of major importance in initiating the breast or other types of cancers. When 
released from the DNA the adducts leave apurinic sites that can generate cancer leading mutations (Cavalieri, 1997).
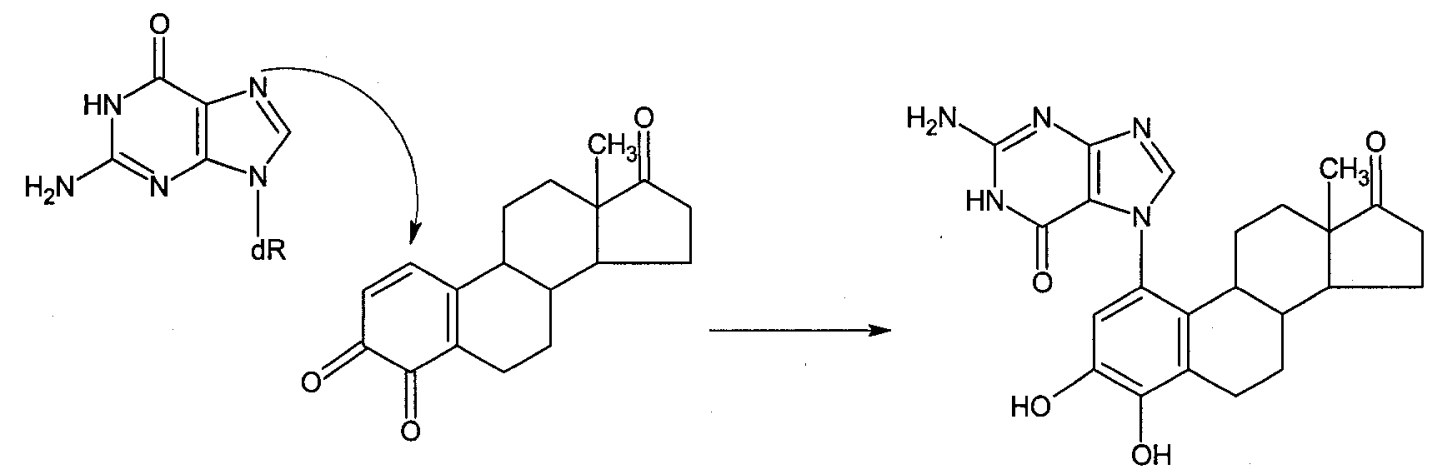

Figure 1.9. Formation of unstable depurinating adducts from the reaction of 4-hydroxyestrone-o-quinone with deoxyguanosine

Cavalieri (2002) showed that in both chemical and enzymatic systems catechol and dopamine derived ortho-quinones react with DNA bases to form predominantly depurinating adducts similar to those formed by the catecholestrogen-3,4- quinones (Figure 1.10).

Levay (1992) studied the formation of DNA adducts in HL-60 promyelocytic leukemia cells when treatyed with hydroquinone, catechol and other benzene metabolites. The results show that hydroquinone is 7 to 9 times more potent than catechol at initiating DNA adduct formation. At the same time the authors found a good correlation between the adduct formation and the cytotoxicity of hydroquione and catechol. Their results suggest that the production of DNA adducts may play a significant role in the toxicity of benzene in vivo. 


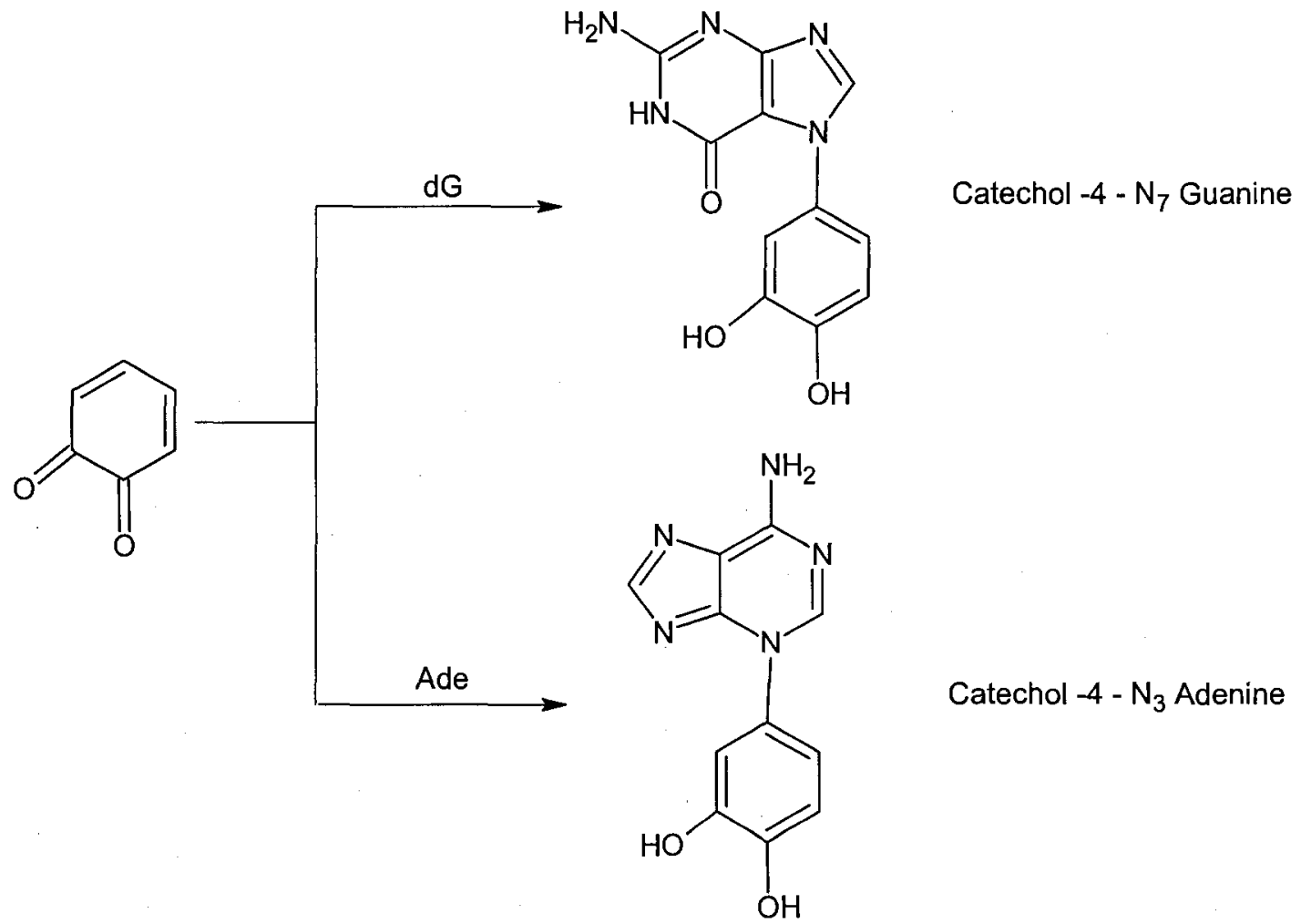

Figure 1.10. Synthesis of Catechol-4-N $\mathrm{N}_{7}$ Guanine and Catechol-4$\mathrm{N}_{3}$ Adenine by reaction of Catechol quinone with 2'-Deoxyguanosine or Adenine

\subsubsection{ROS generation by quinones through redox cycling}

As mentioned above, aside from their ability to act as electrophiles, quinones can induce cellular toxicity by catalyzing reactions producing the superoxide anion. The catalytic activity is based on the quinone's ability to accept electrons from biological reductive species and donate then to molecular oxygen, thus generating superoxide. As shown in Figure 1.11, the intermediate is the semiquinone radical anion. 

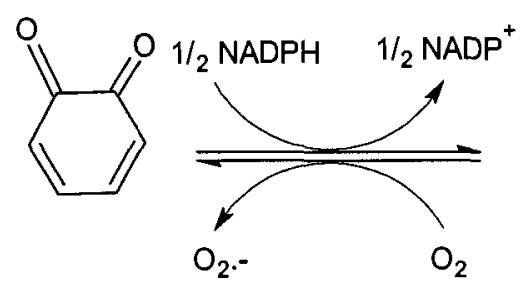

Quinone

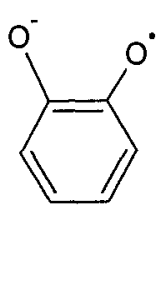

Semiquinone radical anion

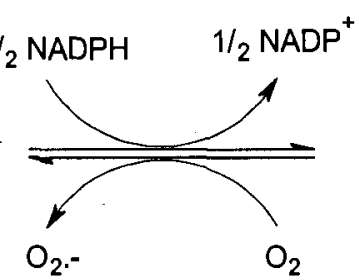

(n)

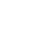

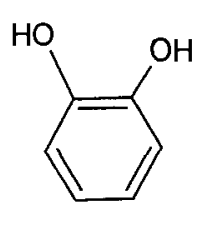

Hydroquinone

Figure 1.11. Generation of ROS by redox cycling

For the whole process to take place, the quinones have to be potent oxidants to accept an electron from the biological reductant and the semiquinone anion has enough reductant potential to efficiently reduce oxygen. Several flavoproteins including NADPH cytochrome P-450 reductase, $\mathrm{NADH}$-cytochrome b5 reductase and $\mathrm{NADH}$ ubiquinone oxidoreductase have been reported to catalyse the one-electron reduction of quinone using NADPH or NADH as reducing equivalents (Powis, 1980). Quinones can also undergo two-electron reductions by NADPH quinone oxidoreductase, also known as DT-diaphorase, to generate the corresponding hydroquinones (Cadenas, 1995).

Quinones can also be reduced non-enzymatically by cellular reducing agents, like ascorbic acid. The reduction by ascorbate involves a one-electron transfer to the quinone to generate the semiquinone radical and ascorbyl radical. Pethig (1983) has monitored the formation of these two radicals by ESR. Since the semiquinone anion $(\mathrm{pKa}=7.0)$ can reduce molecular oxygen, the quinone species act as catalysts for the reduction of oxygen by ascorbic acid. 
The redox cycling process affects the cytotoxicity mechanism in two ways. Firstly it consumes the cellular reducing power (NADPH or NADH) taking it away from regular cellular processes. Secondly it generates superoxide anion that can irreversibly change functional cellular macromolecules (i.e. lipid peroxidation). By disproportionation, superoxide anion quickly produces hydrogen peroxide which is a known oxidant in biological systems.

\subsection{Effects of diols on intracellular GSH content}

Glutathione (L-gamma-glutamyl-L-cysteinylglycine) is a tripeptide present in very high concentration inside the cells; up to $10 \mathrm{mM}$. (Syrus, 2000). It represents the major low molecular weight thiol in the cell and is also the first line of defence against endogenous and exogenous electrophiles (Dickinson, 2002). It is located in cytoplasm, mitochondria, cytosol and nucleus (Ault, 2003). Glutathione is present in three forms: reduced (GSH) and oxidized as disulfide with itself (GSSG) or thiol-protein (GS-SProtein). Under physiological conditions, the ratio between reduced and oxidized varies from ten to a hundred (Filomeni, 2002).

Glutathione has numerous biological functions such as: cysteine storage, redox buffer, reducing power and conjugation with xenobiotics as part of the detoxification process. Alterations in GSH concentration can induce cellular apoptosis or play roles in neurodegenerative disease like Parkinson's or Alzheimer's (Syrus, 2000).

Under oxidative stress, a total glutathione depletion occurs (Mytilineou, 2002). To cope with this situation, the cells try to maintain their redox status 
by different mechanisms: 1) de novo synthesis of glutathione by activation of $\gamma$-GCS ( $\gamma$-glutamyl cysteine synthese) - the rate limiting enzyme of glutathione biosynthesis or 2) the recycling of $\mathrm{GSH}$ from GSSG by activation of glutathione reductase (GR). If the oxidative attack is too long or too strong, then the cells will not be able to produce continuously GSH, fast enough or reduce it quickly enough and the cells will die (Filomeni, 2002 and Ault, 2003).

An increase in intracellular glutathione is a common response towards extracellular toxins. Ishige (2001) showed that quercitin, fisetin, propyl gallate and methyl caffeate, after 10 hours of incubation, increase the intracellular levels of glutathione between 30 and $80 \%$ with respect to the control cells. Dickinson (2003) suggested a correlation between the changes in the GSH levels and different polyphenols from an adaptive point of view. The "adaptive response" is the way the cells subjected to non-toxic stimuli react to future stresses that would usually kill the cells. It has been proposed that some compounds, like dietary constituents or nitric oxide, are protecting against oxidative stress by inducing an "adaptive response" in cells, preparing them for the possible subsequent oxidative event. Eftekhat (2000), while studying the effect of t-butylhydroquinone on neuronal cells, observed that astrocytes respond to this oxidant by doubling the amount of glutathione in 24 hours. In 2002, Bharath published his results concerning the effect of R-lipoic acid on GSH levels in PC12 cells. Under two different sets of conditions, lipoic acid was able to upregulate cellular glutathione. When cells were treated with the compound alone, an almost 1.6 fold increase was observed but, at the same time, no increase in $\gamma \mathrm{GCL}(\gamma$-glutamyl-cysteine ligase) activity was recorded. They explained this behaviour based on the antioxidant activity of lipoic acid 
that can spare the glutathione. When the cells were first treated with BSO (buthionine sulfoximine), an irreversible inhibitor of $\gamma \mathrm{GCL}$, to lower the intracellular GSH content and then subjected to the lipoic acid, the upregulation of glutathione and an increase in $\gamma \mathrm{GCL}$ activity was observed. This confirms the results of Han (1997) that showed an increase in the de novo synthesis of GSH by treatment with lipoic acid. A very comprehensive study on the glutathione up-regulation effect of various phenolic compounds was done in 1996 by Han. Catechol and hydroquinone were both able to elevate cellular GSH content; up to almost twice the amount in the control cells. On the other hand, resorcinol did not have any effect. Both dopamine and L-DOPA markedly increased glutathione levels in mesencephalic cultures. By comparing the structure of the different tested compounds, the authors reached the conclusion that the ability to elevate intracellular GSH content is correlated to their capacity to autooxidize. The fact that, as a result of oxidation of catechols and other diols, free radicals (semiquinones, superoxide anion, etc) and stable oxidants (quinones, hydrogen peroxide) are produced supports the idea that the up-regulation of glutathione is initiated by an oxidative process.

\subsection{Menadione}

Menadione (2-methyl-1,4-naphthoquinone), also known as Vitamin $K_{3}$, is one of the simplest biologically relevant quinones and, by far, the most studied one. The intensive studies were in part connected to its therapeutic applications. Menadione has multiple uses: in multivitamin supplements, hypothrombinemia therapeutic agents, anti-inflammatory and anticancer drugs 
(Chung, 1997 and Lee, 2001). At the same time, these studies have shown that menadione is a cytotoxic agent in different cell and tissue types. Its harmful effects are the result of both redox cycling and alkylation of cellular components via Michael addition reactions. (Lee, 2001). During redox cycling, menadione permeates easily through the cell membrane and, under the action of cytochrome P450 or ubiquinone-oxidoreductase, undergoes a oneelectron reduction to the semiquinone radical. The semiquinone then begins to redox cycle (Bergmann, 1992).

Many studies have shown in most of the cases that treatments with menadione cause a decrease in the intracellular GSH levels. This effect was attributed to the conjugation of menadione with glutathione. The arylation mechanism of toxicity for menadione is not limited to GSH. Menadione can also attach to proteins, thus altering their enzymatic activities (McAmis, 2003). May (2003) found that menadione induced a two-fold increase in oxidative stress in endothelial cells compared to the control cells, as measured by the intracellular oxidation of $2^{\prime}, 7^{\prime}$-dichlorodihydrofluorescein. The oxidative stress was accompanied by a significant decrease in the cellular GSH content. Thor (1982) reported a similar effect in hepatocytes. At concentrations greater than $35 \mu \mathrm{M}$, menadione induced a rapid decrease in glutathione levels in rat hepatocytes. At lower concentrations, the cells were quite resistant to menadione while at $40 \mu \mathrm{M}$ and above, the intracellular GSH content reached close to zero values. When incubated with menadione, endothelial cells suffered a huge decrease in the cellular GSH levels. Ten to fifteen $\mu \mathrm{M}$ menadione reduced the glutathione by $90 \%$ with respect to the untreated cells. Likewise, GSSG exhibited a similar decrease. These data support the 
idea that menadione's cytotoxicity is due mainly to the dramatic changes in cellular GSH content and less to ROS generation by redox cycling (McAmis, 2003). To further investigate the connection between menadione and glutathione, Chang (1992) studied the toxicity of menadione on endothelial cells in both the absence and presence of extracellular GSH. As expected, menadione caused a time-dependent depletion of glutathione, followed by a dose and time-dependent loss of intracellular ATP. Since the formation of GSH adducts with menadione seems to be omnipresent and an important cause of toxicity, the authors measured the formation and elimination in the medium of the conjugates that, once eliminated, did not diffuse back into the cells. The increase in extracellular adducts was directly correlated to the decrease in intracellular glutathione levels. Moreover, the authors were able to observe a time and dose-dependent accumulation of hydrogen peroxide in the culture media. The loss of intracellular GSH can be explained by the formation of adducts with menadione and by the reaction with the hydrogen peroxide produced as a result of redox cycling. Conjugation with glutathione does not hinder menadione's ability to redox cycle but the rapid elimination of the resulting adducts in the medium limits the relative importance of oxidation on the whole mechanism of menadione cytotoxicity. The findings together with the good correlation between GSH depletion and conjugates accumulation in the extracellular space suggest that the latter process accounts for most of the cellular glutathione loss.

Extracellular GSH can protect the cells from menadione by forming adducts before entering the cells, thus limiting the exposure, or by helping intracellular glutathione production. Chang, 1992, observed both the 
extracellular formation of GSH conjugates with menadione in the absence of cells and maintenance of the cellular glutathione pool mediated by $\gamma$-glutamyl transpeptidase. The most important mechanism is proposed to be the extracellular conjugation of menadione with GSH. Other studies (Gant, 1988; Chung, 1997) support the general idea that the formation of Michael adducts between glutathione and menadione plays a more important role than redoxcycling-induced oxidative stress.

Only few studies were carried out on the antioxidant activity and cytotoxicity of menadiol, menadione's parent hydroquinone. Tampo (1996) has measured the antioxidant action of menadiol in a chemical system. Menadiol proved to be more effective than $\alpha$-tocopherol in scavenging free radicals generated by 1,1-diphenyl-2-picrylhydrazyl (DPPH). In a biochemical system (liposomes) menadiol showed initially an antioxidant effect, followed by a marked prooxidant effect. Addition of SOD (superoxide dismutase) was able to counteract the prooxidant action, the antioxidant effect persisting for longer time.

Watanabe (2003) studied the cytotoxicity of hydroquinones in general using as models menadiol and menadione. To explain their results, they proposed a mechanism by which the quinone (menadione) enters the cells and under the effect of NQO1 (NADPH quinone oxidoreductase or DTdiaphorase), it is reduced to the hydroquinone (menadiol). Menadiol diffuses outside the cells and autooxidizes yielding hydrogen peroxide and semiquinone radical that can reduce molecular oxygen to superoxide anion, thus regenerating the quinone that can re-enter the cells and close the cycle. Extracellular disproportionation between quinone and hydroquinone can 
generate semiquinone radical. The semiquinone can reduce $\mathrm{O}_{2}$ to $\mathrm{O}_{2}{ }^{-}$, inducing even more oxidative stress.

\subsection{Hypothesis and aims}

Initially the study started as part of a multidisciplinary and multilaboratory collaboration aimed at developing new synthetic antioxidants. Once several structures were proposed and synthetized, the question of their biological effects was asked. Preliminary tests were encouraging, the tested diols exhibiting antioxidant activity in vivo. The biological effects were not limited to testing their antioxidant potency, but also their toxicity, comparing natural and synthetic antioxidants currently on the market.

The present thesis initially tested the cytotoxicity of the de novo diols and expanded to research their mechanisms of toxicity and how to improve the design in order to reduce their negative biological impact. The goal of the thesis was to try to pinpoint the primary, most important mechanism of toxicity of the benzene diols and naphthalenediols tested. The thesis further proposes structural motifs that would improve the cellular tolerance to future related compounds.

By designing new diols in which the possible sites for adduct formation are blocked, their ability to take part in Michael addition- type reactions was eliminated, thus allowing us to hypothesize that formation of ROS would be the major cause of cytotoxicity of synthetic diols and naphthalenediols. It was also hypothesized that hydrogen peroxide was the major ROS involved and that added catalase will dramatically reduce the observed cellular toxicity. 
The main hypothesis of the thesis is, therefore, that unblocked diols generate ROS (primarily hydrogen peroxide) and that this is the primary source of cellular toxicity. It was proposed that quenching of ROS generated by diols will ameliorate cell death upon diol treatment.

The early observation that there is a structural hinderence in the formation of the quinone product, and thus ROS, of the 2,3-naphthalenediol derivative suggested that new compounds with reduced overall detrimental effects to the cells (i.e. lower toxicity and reduced hydrogen peroxide levels) can be designed. 
Chapter 2

MATERIALS AND METHODS 


\subsection{Chemicals}

Phosphate buffered saline (PBS), trypan blue, dimethyl sulfoxide (DMSO), catalase, 3-(4,5-dimethylthiazol-2-yl)-2,5-diphenyltetrazolium bromide (MTT), Hank's Balanced Sait Solution (HBSS), xylenol orange, sorbitol, ferrous sulfate, 5,5'-dithiobis(2-nitrobenzoic acid) (DTNB), sulfosalicylic acid, gluthathione, nicotinamide adenine dinucleotide phosphate (reduced form; NAPDH), sodium phosphate and menadione were all purchased from Sigma (St. Louis, MO). All cell culture media components were purchased from Invitrogen (Carlsbad, CA)

\subsection{Cell culture}

An adherent line of rat adrenal pheochromocytoma cells (PC12-AC) was a kind gift from Dr. Steffany Bennett (Department of Biochemistry, Microbiology and Immunology, University of Ottawa). Cells were cultivated on $150 \mathrm{~cm}^{2}$ tissue culture flasks (VWR) in RPMI 1640 medium supplemented with $10 \%$ heat-inactivated horse serum, $5 \%$ newborn calf serum and $3 \%$ antibiotics $(100 \mathrm{U} / \mathrm{mL}$ penicillin $\mathrm{G}$ sodium salt, $100 \mu \mathrm{g} / \mathrm{mL}$ streptomycin sulfate and $0.025 \mathrm{mg} / \mathrm{mL}$ Amphotericin B). Cells were grown in a $37^{\circ} \mathrm{C}$ incubator at in a humidified atmosphere of $5 \% \mathrm{CO}_{2}$ in air, being passed twice a week at a density of $5 \times 10^{5}$ cells $/ \mathrm{mL}$. Cells between approximately 4 and 18 passages were used in experiments with a doubling time being approximately 24 hours.

\subsection{Tested compounds}

H1 (4-methoxy-3,5,6-trimethylbenzene-1,2-diol), H1-DA (DA = diacetate), H2 (2,6,7-trimethyl-2,3-dihydroxybenzofuran-4,5-diol), H2-DA, H4 
(4-methylbenzo[1,3]dioxole-5,6-diol), H4-DA, DPND (1,4-dipropylnaphthalene-2,3-diol), DPND-DA, menadiol and menadiol-DA were all synthesized by Dr. Tony Durst (Chemistry Department, University of Ottawa).<smiles>COc1c(C)c(C)c(O)c(O)c1C</smiles><smiles>COc1c(C)c(C)c(OC(C)=O)c(OC(C)=O)c1C</smiles>

\section{2,3,5-Trimethyl-} 4-methoxycatechol H1-DA

Figure 2.1. Chemical structures of H1 and H1-DA<smiles>Cc1c(C)c2c(c(O)c1O)CC(C)O2</smiles><smiles>CC(=O)Oc1c(C)c(C)c2c(c1OC(C)=O)CC(C)O2</smiles>

2,3-Dihydro-2,6,7-trimethyl4,5-dihydroxybenzofuran H2-DA

Figure 2.2. Chemical structures of $\mathrm{H} 2$ and $\mathrm{H} 2-\mathrm{DA}$ 
<smiles>Cc1c(O)c(O)cc2c1OCO2</smiles>

4-Methyl-benzo $[1,3]$ dioxole-5,6-diol (H4)<smiles>CC(=O)Oc1cc2c(c(C)c1OC(C)=O)OCO2</smiles>

H4-DA

Figure 2.3. Chemical structures of $\mathrm{H} 4$ and $\mathrm{H} 4-\mathrm{DA}$.<smiles>CCCc1c(O)c(O)c(CCC)c2ccccc12</smiles>

1,4-Dipropyl-naphthalene-2,3-diol (DPND)<smiles>CCCc1c(OC(C)=O)c(OC(C)=O)c(CCC)c2ccccc12</smiles>

DPND-DA

Figure 2.4. Chemical structures of DPND and DPND-DA<smiles>CC(=O)Oc1cc(C)c(OC(C)=O)c2ccccc12</smiles>

Menadiol-DA<smiles>Cc1cc(O)c2ccccc2c1O</smiles>

2-Methyl-naphthalene-1,4-diol Menadiol<smiles>CC1=CC(=O)c2ccccc2C1=O</smiles>

2-Methyl-[1,4]naphthoquinone Menadione

Figure 2.5. Chemical structures of Menadiol, Menadiol-DA and Menadione 


\subsection{Test for toxicity}

Cell viability (MTT reduction) - PC12-AC cells at $80-100 \%$ confluency were first washed with $10 \mathrm{~mL}$ sterile PBS and then trypsinized for 3 min with 1 $\mathrm{mL} 1 \mathrm{X}$ trypsin $0.5 \%$ EDTA (Invitrogen, Carlsbad, CA) at $37^{\circ} \mathrm{C}$. The enzymatic reaction was then stopped with $4 \mathrm{~mL}$ medium with serum and, in order to break up the clusters, the mixture was pipetted vigorously in a $1 \mathrm{~mL}$ pipette. One hundred $\mu \mathrm{L}$ of cell suspension was added to $250 \mu \mathrm{L}(0.4 \%)$ trypan blue and $150 \mu \mathrm{L}$ PBS and counted on a haemocytometer. Following dilution with medium to a final concentration of 200,000 cells $/ \mathrm{mL}, 100 \mu \mathrm{L}$ of cells were plated on sterile 96-well tissue culture microplates. After allowing the cells to adhere for 24 hours, the supernatant was removed and replaced with $100 \mu \mathrm{L}$ of fresh medium containing the test compounds. One hundred-fold concentrated stock solutions of test compounds were prepared in $100 \%$ DMSO and diluted in PBS prior to adding to cells to give the final concentration used in each experiment. The final concentration of DMSO was less then $0.8 \%$. Stock solutions of catalase were prepared in PBS and added to cells to a final concentration of $1000 \mathrm{U} / \mathrm{mL}$. After another 24 hours of incubation, the medium was removed, the cells washed with $100 \mu \mathrm{L}$ of PBS and $100 \mu \mathrm{L}$ of fresh medium was added. Ten $\mu \mathrm{L}$ of MTT (stock concentration $=$ $5 \mathrm{mg} / \mathrm{mL}$ in PBS) was added and the incubation continued for 2 more hours. Metabolically active cells (with active mitochondrial dehydrogenases) convert the yellow MTT to a blue formazan precipitate with a strong absorbance at $570 \mathrm{~nm}$. After incubation, the supernatant is removed and the cells are lysed with $50 \mu \mathrm{L}$ DMSO, which solubilizes the formazan precipitate. After $15 \mathrm{~min}$, the absorbance is recorded at $570 \mathrm{~nm}$ and corrected by subtracting the 
background absorption at $630 \mathrm{~nm}$. Absorbances were read using a SpectroMAX $340^{\mathrm{PC}}$ microplate reader (Molecular Devices Co., Sunnyvale, CA). The values are normalized to untreated cells which were considered $100 \%$ viable. Data are represented as the mean \pm SEM of three individual experiments, each experiment consisting of 6 subreplicates.

\subsection{Hydrogen peroxide (FOX- ferric oxidase) assay}

Cells were trypsinized, counted and seeded on microplates at a final concentration of 400,000 cells $/ \mathrm{mL}$. After 24 hours of incubation, the medium was removed and $100 \mu \mathrm{L}$ of HBSS containing $100 \mu \mathrm{M}$ of the test compounds in their diacetylated form were added. Stock solutions of the compounds $(25 \mathrm{mM})$ were made in DMSO and diluted one hundred-fold with HBSS to treat cells. Fourty $\mu \mathrm{L}$ of this solution was mixed with $60 \mu \mathrm{L}$ of HBSS and added to the cells. At different time intervals, $10 \mu \mathrm{L}$ of supernatant was removed and used in the FOX assay. The FOX reagent was prepared $30 \mathrm{~min}$ prior to running the assay by mixing 100 parts of color reagent with one part ferrous sulfate reagent. Color reagent was prepared fresh by dissolving xylenol orange in $100 \mathrm{mM}$ sorbitol in double distilled water to a final reagent concentration of $125 \mu \mathrm{M}$ xylenol orange. The ferrous sulfate reagent consisted of a solution of $25 \mathrm{mM} \mathrm{FeSO}_{4}$ in $2.5 \mathrm{M} \mathrm{H}_{2} \mathrm{SO}_{4}$ (Anachemia Canada Inc., Lachine, Quebec). To run the assay, $10 \mu \mathrm{L}$ of the supernatant was mixed with $100 \mu \mathrm{L}$ of the FOX reagent in a separate microplate, incubated for $30 \mathrm{~min}$ at room temperature and then the absorbance at $560 \mathrm{~nm}$ was read using the microplate reader. The absorbance was converted into concentration of $\mathrm{H}_{2} \mathrm{O}_{2}$ by means of a calibration curve of 0 to $80 \mu \mathrm{M} \mathrm{H}_{2} \mathrm{O}_{2}$ (Caledon Laboratories, Georgetown, ON) 
instead of the supernatant. The concentration of the stock solution of hydrogen peroxide was determined using its extinction coefficient at $240 \mathrm{~nm}$ of $0.0394 \mathrm{mM}^{-1}$ (Kulys, 2006)

For autoxidation studies, stock solutions of the compounds $(25 \mathrm{mM})$ in their catecholic (deacetylated) form were prepared in DMSO, followed by a 100-fold dilution HBSS to the working concentrations. A microplate was prepared with each well containing $100 \mu \mathrm{M}$ of the test catechols. At different time intervals, $10 \mu \mathrm{L}$ of the solution were removed and used to run the FOX assay as described above.

\subsection{Extracellular quinone assay}

Two hundred and fifty $\mu \mathrm{M}$ deacetylated compound was tested by diluting the $25 \mathrm{mM}$ stock in DMSO by 100 -fold with HBSS. After complete overnight air oxidation and observation of change in colour, full visible spectra (220 to $800 \mathrm{~nm}$ ) were obtained and the optimum wavelength for each test compound was as follows: $460 \mathrm{~nm}$ for $\mathrm{H} 1\left(192 \mathrm{M}^{-1} \mathrm{~cm}^{-1}\right), 520 \mathrm{~nm}$ for $\mathrm{H} 2\left(232 \mathrm{M}^{-}\right.$ $\left.{ }^{1} \mathrm{~cm}^{-1}\right)$ and $350 \mathrm{~nm}$ for $\mathrm{H} 4\left(500 \mathrm{M}^{-1} \mathrm{~cm}^{-1}\right)$. Tests were done on microplates using $100 \mu \mathrm{L}$ samples. Standard curves of compounds were constructed using 0 to $100 \mu \mathrm{M}$ of the compounds. PC12-AC cells undergoing exponential growth were washed, trypsinized, counted and seeded on microplates to a final concentration of 400,000 cells $/ \mathrm{mL}$. After 24 hours of incubation at $37^{\circ} \mathrm{C}$ in $5 \%$ $\mathrm{CO}_{2}$ humidified air, the medium was replaced with $100 \mu \mathrm{L}$ of a $100 \mu \mathrm{M}$ solution of diacetylated compound in HBSS. Time course experiments were performed by removing $100 \%$ of the supernatant and by reading the absorbance at the corresponding wavelength for the studied catechol. Using the calibration 
curves, the extracellular quinone concentrations were determined and plotted against time.

\subsection{Glutathione assay}

The assay for reduced glutathione $(\mathrm{GSH})$ is based on the rate of reaction between GSH and DTNB (Tietze, 1969). PC12-AC cells (approximately $80-100 \%$ confluent on $150 \mathrm{~cm}^{2}$ Falcon flasks) were washed with $10 \mathrm{~mL}$ PBS, trypsinized for $3-5$ minutes with $1 \mathrm{~mL}$ of $1 \times$ trypsin-EDTA, pipetted vigorously with a $1 \mathrm{~mL}$ pipette to break up cell clusters, counted and diluted to a final concentration of 400,000 cells $/ \mathrm{mL}$. Eight $\mathrm{mL}$ of this stock solution was placed on $10 \mathrm{~cm}$ untreated dishes and incubated for 4 hours to allow cell adherence. After removal of the supernatant, new medium containing the test compounds ( 0 to $150 \mu \mathrm{M}$ ) was added. As previously mentioned, the compounds in their DA form were first dissolved in DMSO to make $25 \mathrm{mM}$ stock solutions and further diluted 100 -fold with PBS to prepare working solutions of $250 \mu \mathrm{M}$. Cells were incubated for 3 or 24 hours in control conditions at $37^{\circ} \mathrm{C}$ and $5 \% \mathrm{CO}_{2}$ humidified air. Cells were then washed once with $5 \mathrm{~mL}$ of PBS, harvested with a cell scraper and collected with $1 \mathrm{~mL}$ PBS in $15 \mathrm{~mL}$ centrifuge tubes. After centrifugation for $5 \mathrm{~min}$ at $1,000 \mathrm{rpm}$ in a IEC Multi RF Multipurpose Benchtop Centrifuge (Thermo IEC, Needham Heights, MA), the supernatant was discarded and cell pellets were quickly lysed in $50 \mu \mathrm{L}$ of $5 \%$ iced-cold sulfosalicylic acid, previously bubbled with $\mathrm{N}_{2}$ gas for 15 min. Cell lysates were then transferred to an Eppendorf tube (VWR, West Chester, PA, USA, bubbled with $\mathrm{N}_{2}$ for $10 \mathrm{sec}$ and centrifuged for 1 minute at $13,000 \mathrm{~g}$ on a microcentrifuge (Baxter Canlab/NWR, Deerfield IL, USA). 
Supernatants were quickly transferred to new tubes containing $450 \mu \mathrm{L}$ of $0.5 \mathrm{M}$ potassium phosphate $(\mathrm{KPi})(\mathrm{pH}$ 6.0). Twenty $\mu \mathrm{L}$ of the neutralized supernatants were then used in the GSH assay. Cell pellets obtained after high-speed centrifugation were frozen in liquid nitrogen and stored for protein determination. For the GSH assay, two microplates were used, one containing the GSH standard stocks, samples and the glutathione reductase was kept on ice at all times; another was kept at room temperature on the bench and was used to assemble the assay to be read on the microplate reader. Five $\mathrm{mM}$ GSH stocks were prepared in $0.5 \mathrm{M} \mathrm{KP}$ and then diluted with $\mathrm{KP}_{\mathrm{i}}$ to $50 \mu \mathrm{M}$ working solutions. Other solutions required for the assay included $0.3 \mathrm{mM}$ NADPH prepared fresh in stock buffer containing $125 \mathrm{mM} \mathrm{NaH}_{2} \mathrm{PO}_{4} \cdot \mathrm{H}_{2} \mathrm{O}, \mathrm{pH}$ 7.5 , and $6.3 \mathrm{mM}$ sodium EDTA, and 6mM DTNB prepared in stock buffer and a $50 \mathrm{U} / \mathrm{mL}$ glutathione reductase (GR) in stock buffer. In separate wells of the microplate, each assay contained $70 \mu \mathrm{L}$ of the NADPH solution, $10 \mu \mathrm{L}$ of the DTNB solution, a very quick addition of $10 \mu \mathrm{L}$ of the GR solution and finally $20 \mu \mathrm{L}$ of either sample (neutralized supernatants) or standard GSH. Samples were read on the microplate reader using kinetics at $412 \mathrm{~nm}$. A standard curve was composed of the initial rates (slopes) of the standards plotted against GSH content (0-300pmoles). Standard curves were then used to determine the amount of GSH present in samples. For comparison purposes, the GSH content was normalized to the amount of protein measured in the cell pellets.

\subsection{Protein determination}

Soluble protein in cell pellets was measured by the Coomassie blue dye-binding method (Bradford, 1976) using the Bio-Rad Protein Assay (Bio- 
Rad, Hercules, CA). Bovine serum albumin was used as a standard $(0-30 \mu \mathrm{g})$. Cell pellets were thaw and vortexed with $200 \mu \mathrm{L}$ of $\mathrm{KP}_{\mathrm{i}}$ buffer. After centrifugation at $13,000 \mathrm{~g}$ for $1 \mathrm{~min}$, the supernatants were transferred to Eppendorf tubes and used for protein determination. Bio-Rad reagent was diluted 5-fold with distilled water. Twenty $\mu \mathrm{L}$ of protein was added to $150 \mu \mathrm{L}$ of the protein dye reagent. The absorbance at $595 \mathrm{~nm}$ was recorded after 10 minutes incubation at room temperature on a microplate reader. The amount of protein in each sample was determined from the standard curve.

\subsection{Statistics}

Data are represented as mean \pm SEM values. Statistical significance was determined by performing a one-way ANOVA test. The level of significance was chosen to be at $p<0.05$. 
Chapter 3

RESULTS 


\subsection{Cytotoxicity}

The toxicity of synthesized diols was tested on PC12-AC cells. In order to compare the potency of each compound, $\mathrm{EC}_{50}$ values were determined. The effective concentration of catechol that reduced viability of PC-12AC cells by $50 \%$ of controls was taken as the $\mathrm{EC}_{50}$ value. Toxicity curves were constructed for each of the diols in both the presence and the absence of added catalase.

Figure 3.1 shows the changes in viability of $\mathrm{PC} 12-\mathrm{AC}$ cells with respect to the concentration of H1-DA.

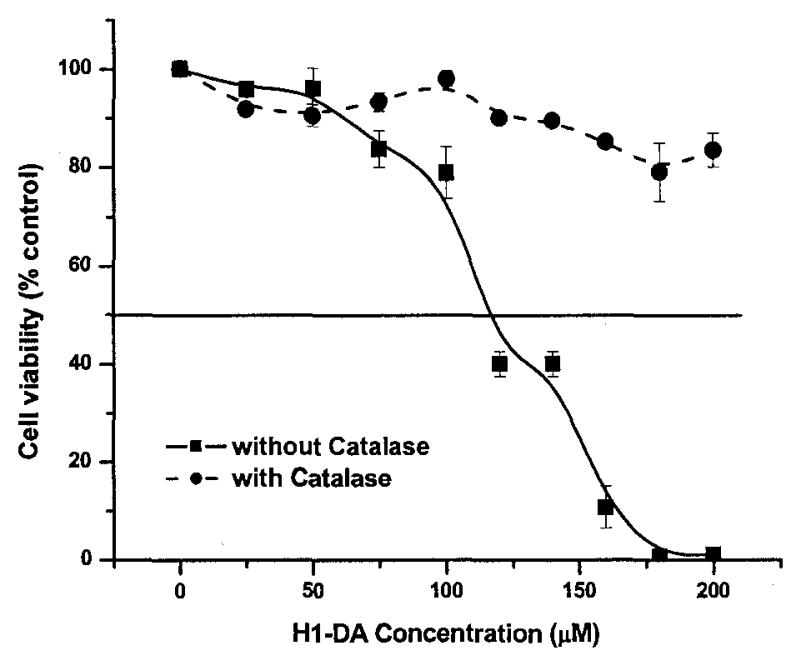

Figure 3.1. Toxicity of H1-DA to PC12-AC cells in the presence and absence of added catalase $(1000 \mathrm{U} / \mathrm{mL})$. Cell viability was determined using the MTT assay. Values represent means \pm S.E.M.

Cells were incubated with H1-DA at concentrations ranging from 0 (control) to $200 \mu \mathrm{M}$ and cell viability was determined by using the MTT assay. For the simple treatment with just the catechol, an $\mathrm{EC}_{50}$ value of $116 \mu \mathrm{M}$ was obtained. When $1000 \mathrm{U} / \mathrm{mL}$ of catalase was co-incubated with the diol, its 
toxicity decreased so that the $\mathrm{EC}_{50}$ was not reached; even when up to $200 \mu \mathrm{M}$ concentrations were used.

With H2-DA, the concentrations used to test its toxicity ranged from 0 to $60 \mu \mathrm{M}$, with the $\mathrm{EC}_{50}$ being determined to be $53 \mu \mathrm{M}$, as shown in Figure 3.2.As with H1-DA.

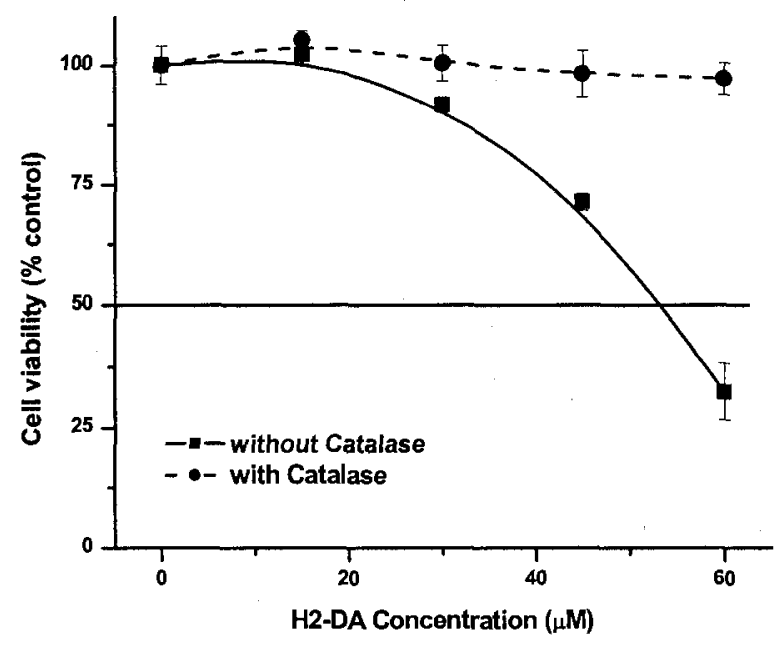

Figure 3.2. Toxicity of H2-DA to PC12-AC cells in the presence and absence of catalase. Cell viability was determined using MTT assay. Values represent means \pm S.E.M.

A significant reduction in toxicity was observed with H2-DA when treated in presence of $1000 \mathrm{U} / \mathrm{mL}$ catalase.

Similarly, the toxicity of H4-DA to PC12-AC was tested both in the presence and the absence of catalase. The testing was done on a narrower range; from 0 to $60 \mu \mathrm{M}$. As shown in Figure 3.3, the $\mathrm{EC}_{50}$ value was $30 \mu \mathrm{M}$ in the absence of catalase and was not reached when it was present. Catalase was clearly efficient at reducing the cytotoxicity of all catechols tested. 


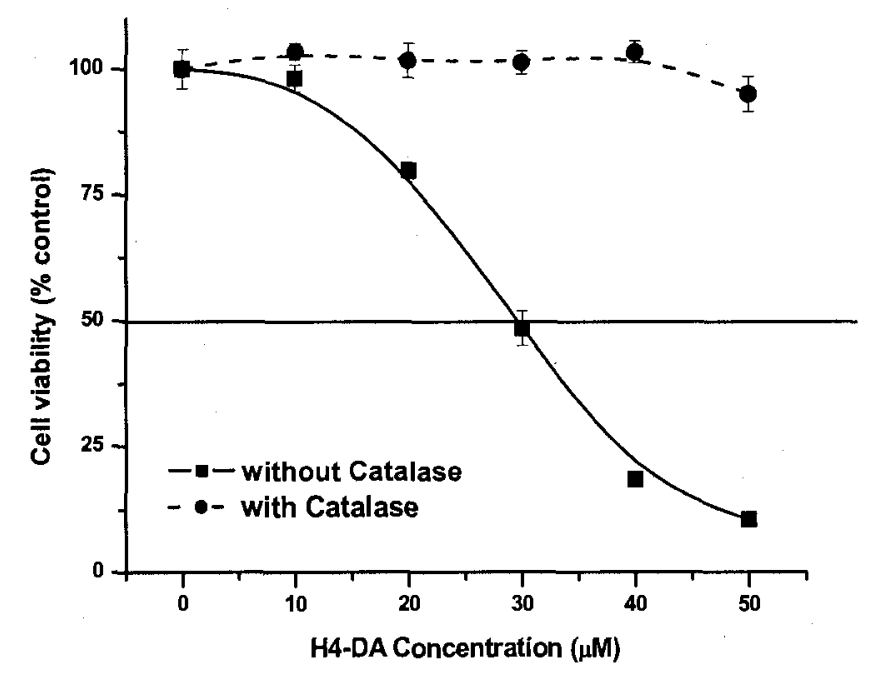

Figure 3.3. Toxicity of H4-DA to PC12-AC cells in the presence and absence of catalase. Cell viability was determined using MTT assay. Values represent means \pm S.E.M.

This was not the case when the naphthalenediol DPND-DA was tested for toxicity to PC12-AC cells. First, the toxicity proved to be much lower than the catechols. The $\mathrm{EC}_{50}$ value increased to $157 \mu \mathrm{M}$. Catalase only slightly decreased the toxicity of DPND-DA. An $\mathrm{EC}_{50}$ value of $200 \mu \mathrm{M}$ was obtained when catalase was included in the medium. Figure 3.4 shows the toxicity curves for DPND-DA in the presence and absence of catalase. 


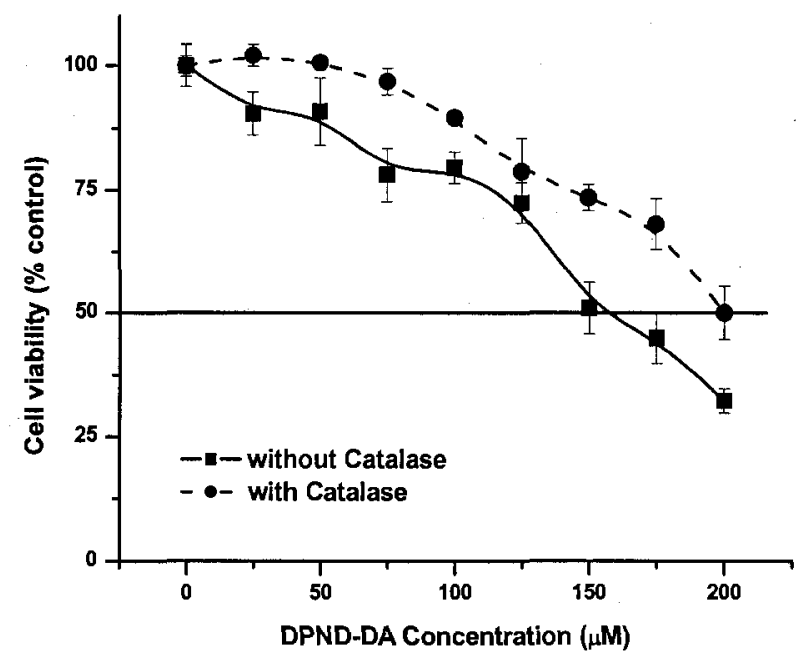

Figure 3.4. Toxicity of DPND-DA to PC12-AC cells in the presence and absence of catalase. Cell viability was determined using MTT assay. Values represent means \pm S.E.M.

\subsection{Hydrogen peroxide production}

Since one of the most common mechanisms of catechol/quinone toxicity is redox cycling, it was imperative to try to quantify its overall importance in toxicity to cells. Since hydrogen peroxide is the end product of the redox cycling, its production was measured in the presence of PC12-AC cells when incubated with synthetic diols. For the ease of experimental procedure and of comparison between the four test compounds, only one concentration $(100 \mu \mathrm{M})$ of the test compounds was used. The time course for the production of hydrogen peroxide in the extracellular medium for all four diols is shown in Figure 3.5. 


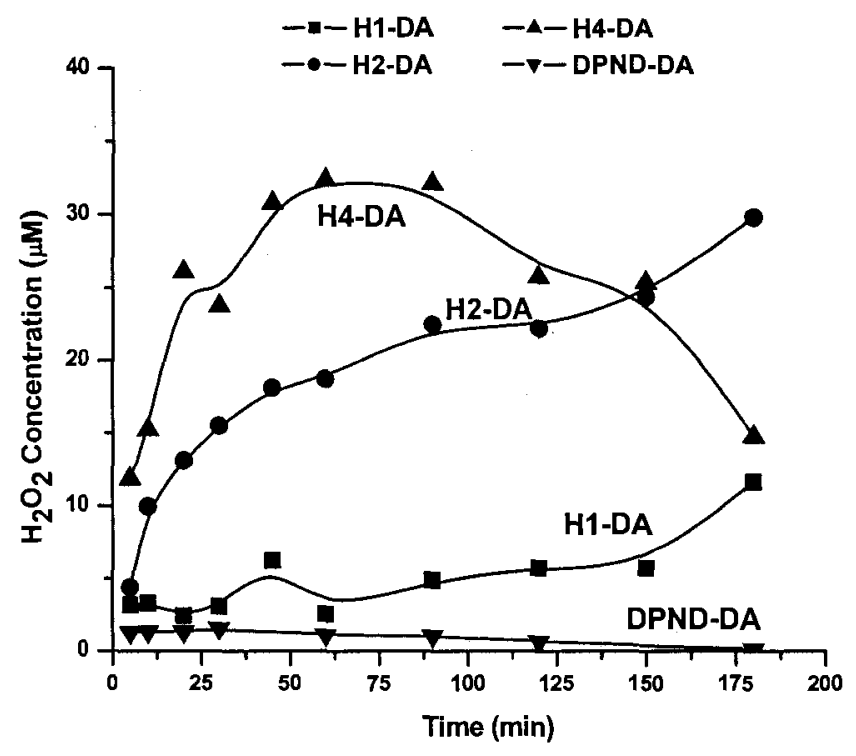

Figure 3.5. Extracellular hydrogen peroxide in the medium when PC12AC cells were incubated with $100 \mu \mathrm{M}$ of each of the test compounds.

There was a definitive difference in hydrogen peroxide production between the catechols and the naphthalenediol. There was a rise in the amount of extracellular hydrogen peroxide produced over time for all catechols used while there was a marked decrease in the extracellular hydrogen peroxide produced when using the naphthalenediol.

H1-DA showed a steady, slow increase of hydrogen peroxide over time, reaching a maximum of $10 \mu \mathrm{M} \mathrm{H}_{2} \mathrm{O}_{2}$ accumulated in the three hours of testing. The initial rate (first 20 minutes) of hydrogen peroxide produced when PC12-AC cells were treated with $100 \mu \mathrm{M}$ H2-DA was very fast. Hydrogen peroxide production continued at a steady rate until it reached a maximum of $30 \mu \mathrm{M} \mathrm{H} \mathrm{H}_{2} \mathrm{O}_{2}$ produced in the three hours of testing. $\mathrm{H} 4$-DA produced hydrogen 
peroxide at the fastest rate, resulting in $35 \mu \mathrm{M}$ of hydrogen peroxide being produced within the first sixty minutes of assaying. It was the only catechol that showed a drop in extracellular hydrogen peroxide concentration after one hundred minutes. The drop resulted in only $15 \mu \mathrm{M}$ of hydrogen peroxide being produced at the end of three hours of testing.

Many studies have demonstrated that the autoxidation of catechols, in the absence of cells, is responsible for a large portion of their toxicity. In order to take this into consideration, the formation of hydrogen peroxide as a result of autoxidation in HBSS (the medium used in cellular tests) in a cell-free system and the FOX assay was run using $100 \mu \mathrm{M}$ of each of the compounds in their deacetylated form (so that their free $\mathrm{OH}$ groups can take part in the autooxidation process without being blocked by the acetyl moieties).

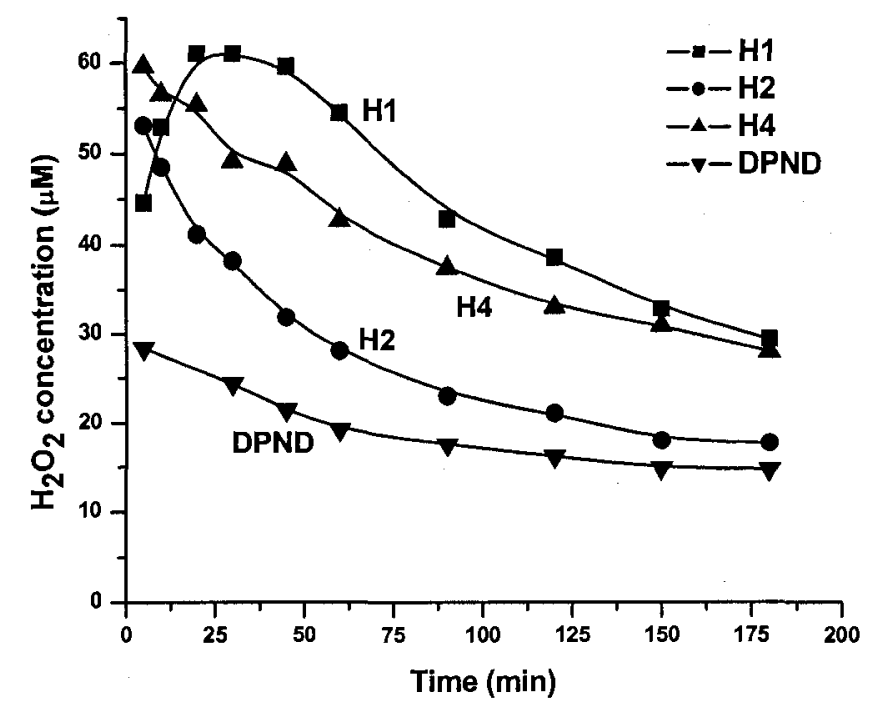

Figure 3.6. Hydrogen peroxide time course for the autoxidation of $100 \mu \mathrm{M}$ of each of the tested compounds in HBSS 
The differences in behaviour observed between the catechols and the naphthalenediol held true in all experimental results. $\mathrm{H} 1$ started with a fast autoxidation rate, reaching a maximum of $60 \mu \mathrm{M} \mathrm{H}_{2} \mathrm{O}_{2}$ produced after only 25 minutes of incubation. Following this increase, a sharp decrease in the amount of hydrogen peroxide produced was observed, such that after 3 hours, only half of the original levels of hydrogen peroxide were present in the medium.

Based on the results, it can be concluded that $\mathrm{H} 2$ is a very reactive compound. It is completely oxidized within the first 5 minutes of addition to HBSS, as indicated by the peak of hydrogen peroxide of approximately $55 \mu \mathrm{M}$. For the next 3 hours a continuous and rapid disappearance of the $\mathrm{H}_{2} \mathrm{O}_{2}$ was observed, with only $20 \mu \mathrm{M}$ remaining after 3 hours.

The autoxidation of $\mathrm{H} 4$ was similar to that of $\mathrm{H} 2$. A peak of approximately $60 \mu \mathrm{M}$ hydrogen peroxide was observed in the first $5 \mathrm{~min}$ of incubation, indicating a similar rapid rate of autoxidation as $\mathrm{H} 1$. The subsequent depletion in $\mathrm{H}_{2} \mathrm{O}_{2}$ was steady but not as rapid as that of $\mathrm{H} 1$. Thirty $\mu \mathrm{M}$ of $\mathrm{H}_{2} \mathrm{O}_{2}$ remained after 3 hours of incubation and this may have decreased further if longer incubation times were performed.

As mentioned above, DPND showed a completely different behaviour compared to the catechols. The first and most striking difference consisted of the maximum level of hydrogen peroxide reached in the system; which was only half of the amount produced by the catechols. The maximal amount of hydrogen peroxide produced by DPND occurred at 5 minutes of incubation but the overall $\mathrm{H}_{2} \mathrm{O}_{2}$ levels were less pronounced than those of the catechols. 
Hydrogen peroxide produced by DPND decreased to $15 \mu \mathrm{M}$ at the end of 3 hours.

\subsection{Quinone quantification}

Since the toxicity of catechols is linked to quinone formation, (as oxidation products), the amount of quinones produced by the cells was quantified. Cells were incubated with $100 \mu \mathrm{M}$ of each of the catechols in their acetylated form and the extracellular concentrations of corresponding quinones were measured using a spectrophotometer. The results are presented in Figure 3.7.

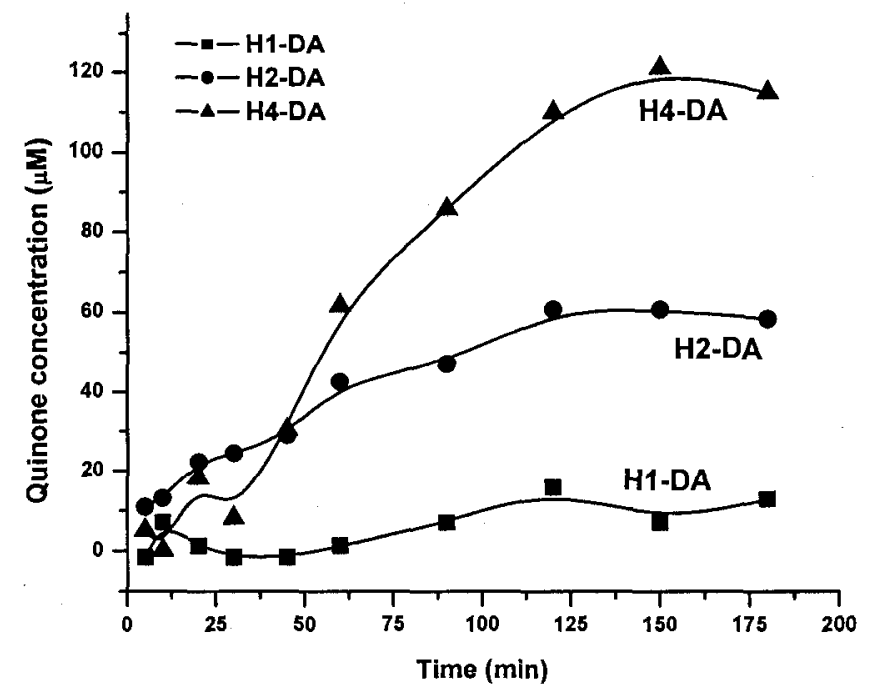

Figure 3.7. Time course for the extracellular levels of quinones measured after incubating $100 \mu \mathrm{M}$ of each of the catechols with 200,000 cells $/ \mathrm{ml}$ of PC12-AC in HBSS.

Despite similarities in both the structures and the autoxidation rates, very significant differences in the efflux of their corresponding quinones were 
observed. In order to measure the quinone, the compounds have to diffuse into the cell, become hydrolyzed and oxidize either inside or outside of the cell to form the quinone that is measured. As shown in Figure 3.7, H1-DA is the slowest to go through the cell. After 3 hours of incubation, only $10 \%$ of the added catechol was measured to be outside the cell in the form of its quinone product. The results indicated the presence of extracellular quinone after 60 minutes of incubation. For the last 2 hours a steady and slow increase of quinone production was observed.

In contrast to the first compound, H2-DA was more rapidly oxidized to its quinone product. Measurable amounts of quinone were detected from the very first minutes of the experiment. At 5 minutes of incubation, $10 \mu \mathrm{M}$ quinone was already present in the system. Following a rapid and continuous increase in the quinone efflux, a steady level of $60 \mu \mathrm{M}$ is reached after 3 hours of incubation. Taking into account that the cells were incubated with $100 \mu \mathrm{M}$ catechol, the results indicated that more than $50 \%$ of the compound was taken up by cells and oxidized to their quinone products.H4-DA had opposite effects compared to H1-DA. Of all the compounds tested, H4-DA had the fastest kinetics. After 120 minutes of incubation, all $100 \mu \mathrm{M}$ of the catechol that was initially added to the system was oxidized to quinone.

\subsection{GSH cellular content}

Glutathione, both reduced (GSH) and oxidized (GSSG), is an exact and sensitive indicator of the redox status of the cells. Since its intracellular concentration reaches as high as $10 \mathrm{mM}$, glutathione acts as the main redox buffer of the cells. As one of the first line of defense against oxidative stress, 
the levels of glutathione in cells are rapidly increased in response to prooxidant conditions (Woods, 1999). It was logical then to measure the changes in the intracellular glutathione concentration due to the incubation of cells with catechols. The results are presented in Figure 3.8.

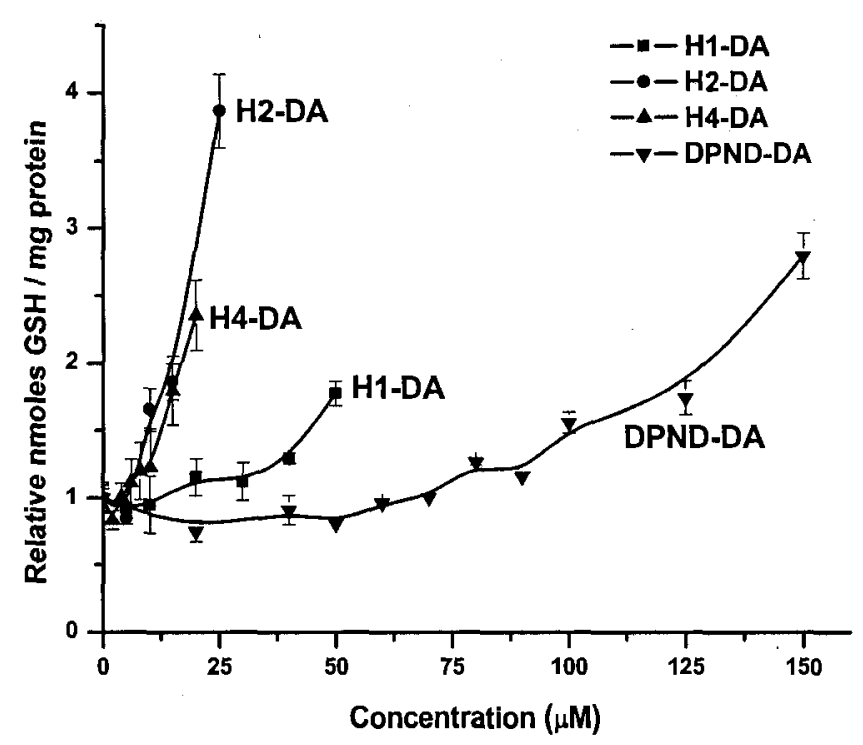

Figure 3.8. Total glutathione (GSH and GSSG) response curves to increasing concentrations of tested compounds in their DA form. The results are normalized to milligram of protein in cell lysate.

Based on their cytotoxicity, different ranges of concentrations for each of the tested catechols were used to measure the glutathione response. The results show that the general cellular response to catechol and naphthalenediol treatment is an up-regulation of the total glutathione levels. Different catechols had different ranges of treatment concentrations as well as the magnitude of the up-regulation. H1-DA showed a steady increase, with $50 \mu \mathrm{M}$ inducing a doubling in the amount of total glutathione compared to the 
untreated cells. H2-DA and H4-DA were similar in their glutathione induction. For both catechols, a dramatic rise in total glutathione is observed over time. After 24 hours of incubation, H2-DA $(25 \mu \mathrm{M})$ induced a four-fold increase in the amount of glutathione produced by the cells, this being the maximum response of all the tested compounds. For H4-DA, the up-regulation of glutathione occurred as rapidly as that of H2-DA treatment, but because H4DA is more toxic (its $\mathrm{EC}_{50}$ is only $30 \mu \mathrm{M}$ compared to $53 \mu \mathrm{M}$ for $\mathrm{H} 2-\mathrm{DA}$ ), a much narrower range of concentrations was used. Nevertheless, a more than two-fold increase in the glutathione level was observed when incubating the cells with $20 \mu \mathrm{M} \mathrm{H} 4-\mathrm{DA}$.

DPND-DA was ineffective in up-regulating glutathione over a broad range of concentrations. No increase in total glutathione was observed until $100 \mu \mathrm{M}$ DPND-DA was added to the cells. Concentrations above $100 \mu \mathrm{M}$ increased glutathione at a steady rate, showing a two-fold increase over control (untreated) values at $150 \mu \mathrm{M}$ DPND-DA.

\subsection{Menadiol and Menadione}

Despite the fact that menadiol is widely used as an oxidative stresser in cell culture, its mechanism of cytotoxicity is not well understood (De Loecker, 1993). Since our approach is to study the toxicity of catechols, we decided to apply the same battery of tests to menadiol treatment. The toxicity of acetylated and non-acetylated menadiol was tested in the presence and absence of added catalase. 


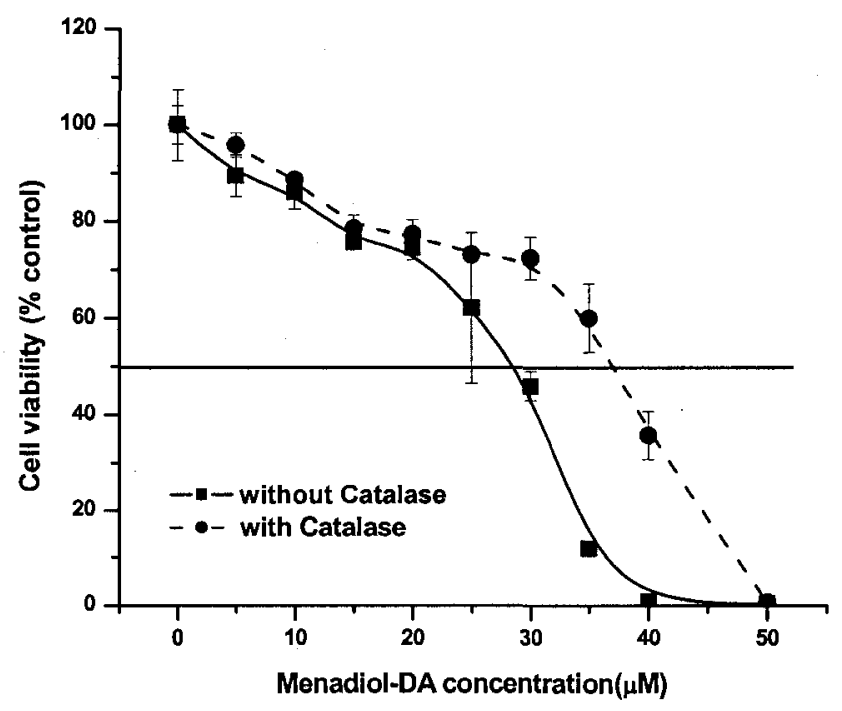

Figure 3.9. Menadiol-DA toxicity to PC12-AC (200,000 cells/mL) after 24 hours of incubation at $37^{\circ} \mathrm{C}$ in the presence and absence of added catalase $(1000 \mathrm{U} / \mathrm{mL})$. (Values represent means \pm S.E.M. $n=3)$.

As shown in Figure 3.9, when treated with increasing concentrations of menadiol-DA, cells had an $\mathrm{EC}_{50}$ of around $28 \mu \mathrm{M}$ menadiol-DA. These results indicated that menadiol-DA is quite toxic compared to the other catechols tested above. Addition of $1000 \mathrm{U} / \mathrm{mL}$ of catalase showed a reduction of menadiol toxicity, yielding an $\mathrm{EC}_{50}$ value of $37 \mu \mathrm{M}$ (representing a $32 \%$ increase, considering the $\mathrm{EC}_{50}$ value for the compound alone with no catalase added as $100 \%$ ). Although this difference was less than what occurred with other compounds, it was significant enough to suggest the involvement of hydrogen peroxide in menadiol-DA induced cytotoxicity. 
Menadiol, in its free hydroxyl form, was also tested for toxicity. In the absence of catalase from the system, menadiol had the highest toxicity of all the compounds tested with an $\mathrm{EC}_{50}$ value of $17.5 \mu \mathrm{M}$.

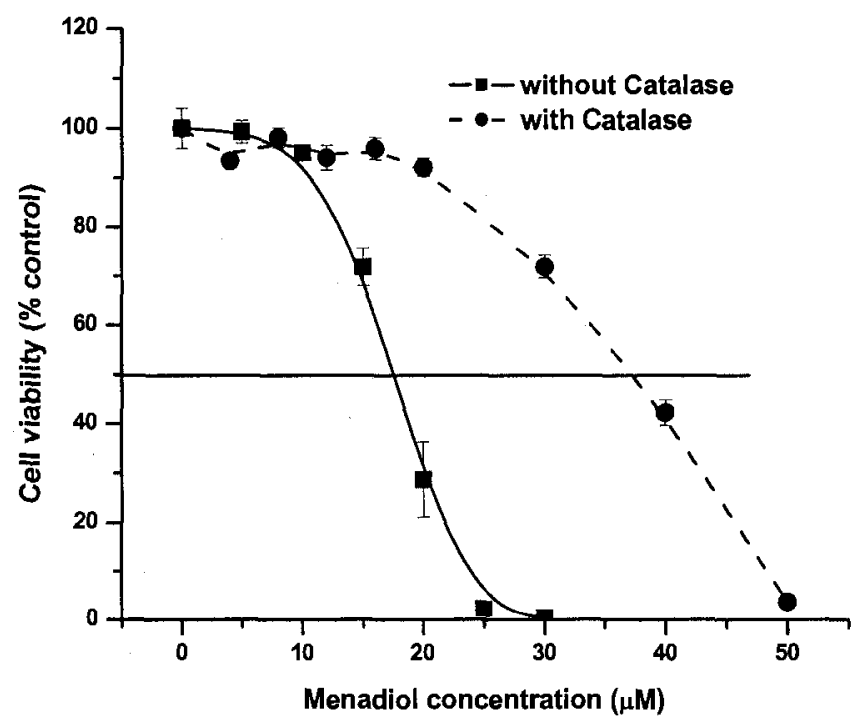

Figure 3.10. Menadiol toxicity to PC12-AC. PC12-AC $(200,000$ cells $/ \mathrm{mL})$ were incubated, with or without catalase $(1000 \mathrm{U} / \mathrm{mL})$ for $24 \mathrm{hrs}$ at $37^{\circ} \mathrm{C}$ and cell viability was measured using MTT assay.

Menadiol was only toxic at higher concentrations $(10 \mu \mathrm{M})$ at which a large drop in cell viability was recorded. At only $25 \mu \mathrm{M}$ menadiol, all the cells were dead. 
Catalase has a more pronounced effect on menadiol's toxicity compared to menadiol-DA. When co-treated with catalase, the $\mathrm{EC}_{50}$ of menadiol was $37.5 \mu \mathrm{M}$, showing a reduction of $214 \%$ in cytotoxicity. The drop in cell viability was less steep in the presence of catalase, occurring over a wider range of concentrations (from 20 to $50 \mu \mathrm{M}$ ).

The last compound tested for toxicity was menadione (Figure 3.11).

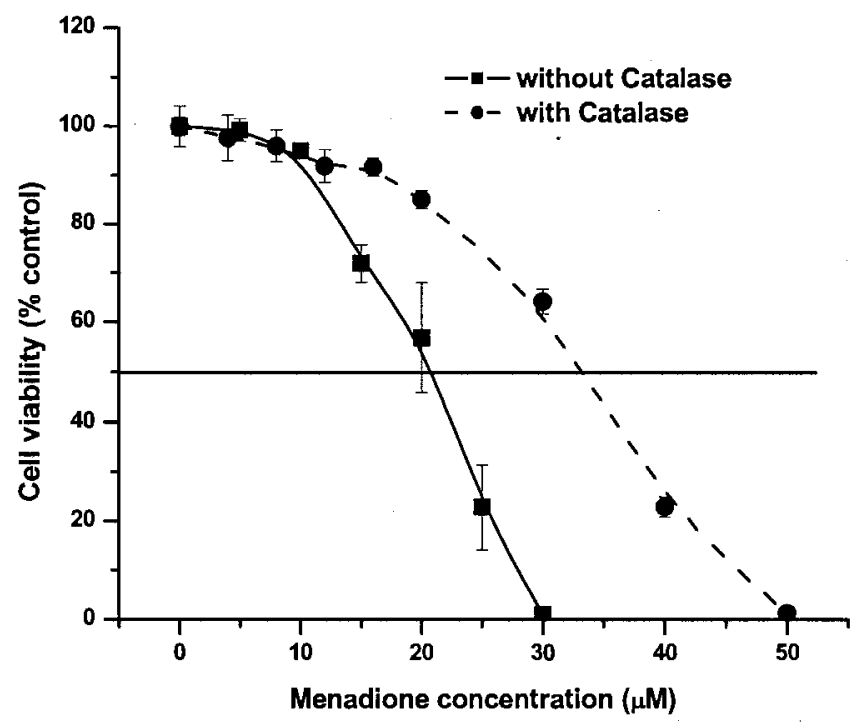

Figure 3.11. Toxicity of menadione to PC12-AC in the presence and absence of catalase $(1000 \mathrm{U} / \mathrm{mL})$. Cell viability was assayed using the MTT test.

With an $\mathrm{EC}_{50}$ value of $21 \mu \mathrm{M}$, it is no surprise that menadione is widely used as cell stressor. The concentrations of menadione required to produce cell death are low. Similar toxicity curves were obtained for both menadiol and menadione: up to $10 \mu \mathrm{M}$ of menadione had almost no effect on cells, after which a sudden drop in cell viability occurs. All cells were dead with $30 \mu \mathrm{M}$ menadione. 
Catalase continues to shows its effect of reduction in cytoxicity; in this case, $33.5 \mu \mathrm{M}$ of menadione co-incubated with $1000 \mathrm{U} / \mathrm{mL}$ catalase was required to kill $50 \%$ of the cells, when compared to control. Again, the drop in cell viability was less dramatic than with menadiol and occurred over a wider range of concentrations.

Table 2.1. $\mathrm{EC}_{50}$ values for all the tested compounds in presence and absence of catalase

\begin{tabular}{|l|c|c|}
\hline \multirow{2}{*}{ Compound } & \multicolumn{2}{|c|}{ EC $_{50}$ values $(\mu \mathrm{M})$} \\
\cline { 2 - 3 } & No catalase & With catalase \\
\hline H1-DA & 116 & $>200$ \\
\hline H2-DA & 53 & $>60$ \\
\hline H4-DA & 30 & $>50$ \\
\hline DPND-DA & 157 & 200 \\
\hline Menadiol-DA & 28 & 37 \\
\hline Menadiol & 17.5 & 37.5 \\
\hline Menadione & 21 & 33.5 \\
\hline
\end{tabular}

The most proposed mechanism for menadione cytotoxicity is glutathione depletion. Since we are testing not only the quinone but also the diol, the levels of glutathione in response to the synthesized compounds was determined. 


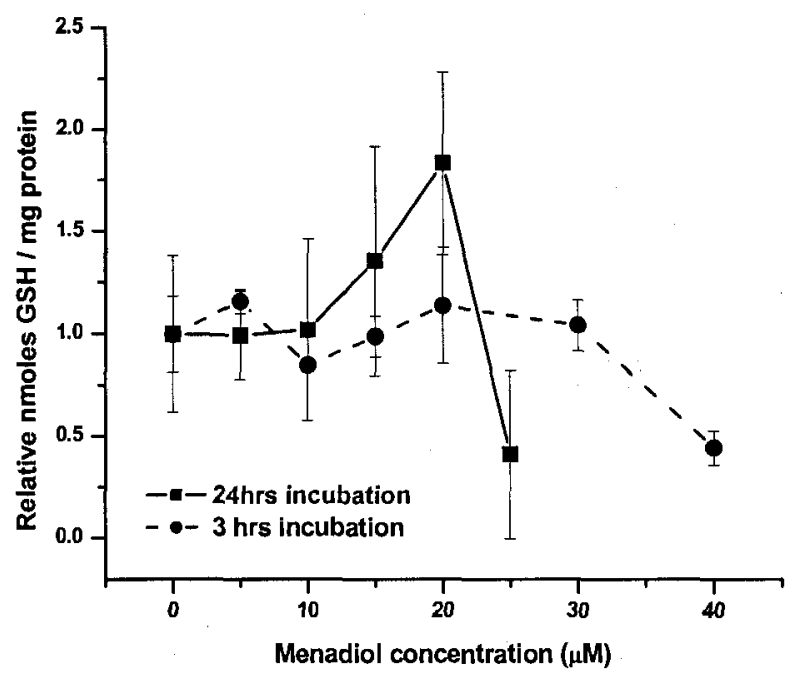

Figure 3.12. Total glutathione response curves to treatment with different concentrations of menadiol for 3 and 24 hours at $37^{\circ} \mathrm{C}$. (Values represent means \pm S.E.M. $n=3$ ).

First, the cellular response after 24 hours of incubation with menadiol was tested. As shown in Figure 3.12, the overall response is an increase in intracellular glutathione; up to two-fold compare to control cells, followed by a dramatic decrease. When taking into account the extremely high toxicity of menadiol $\left(E C_{50}=17.5 \mu \mathrm{M}\right)$, it is reasonable to think that at $25 \mu \mathrm{M}$ menadiol, when almost $80 \%$ of the cells are dead, the glutathione will show a marked decrease. The results were somehow puzzling in that they contradict the literature that proposes glutathione depletion as the main mechanism of toxicity for menadione (Chung, 1997). Despite the fact that menadiol, and not menadione, was tested at this point in time, the diol form will eventually oxidize to quinone. Therefore, there should be no significant difference between their behaviour relative to intracellular glutathione levels. In this case, 
the experiment was repeated, allowing the cells to be incubated for only 3 hours with menadiol. This test was successful (Figure 3.12), showing that for short incubations there is an important reduction in glutathione to approximately half of that in control cells with $40 \mu \mathrm{M}$ of menadiol. This shows that initially the cells are suffering an acute depletion in intracellular glutathione. However, as a result of this oxidative stress, the cells react by upregulating glutathione metabolism in order to counteract menadiol's toxicity Finally, menadione was tested on PC12-AC cells for effects on glutathione levels. Both short and long time incubation experiments were run and glutathione, normalized to $\mathrm{mg}$ of protein in cells lysate pellets, was measured.

For 24 hour incubations (Figure 3.13), a rapid and very steep increase in the glutathione levels in PC12-AC cells occurred with $30 \mu \mathrm{M}$ menadione treatment. Glutathione levels increased four-fold compared to control cells. As was the case for menadiol, at concentrations near $\mathrm{EC}_{50}$, total glutathione peaks at low concentrations of menadione followed by a decrease due to cell death. 


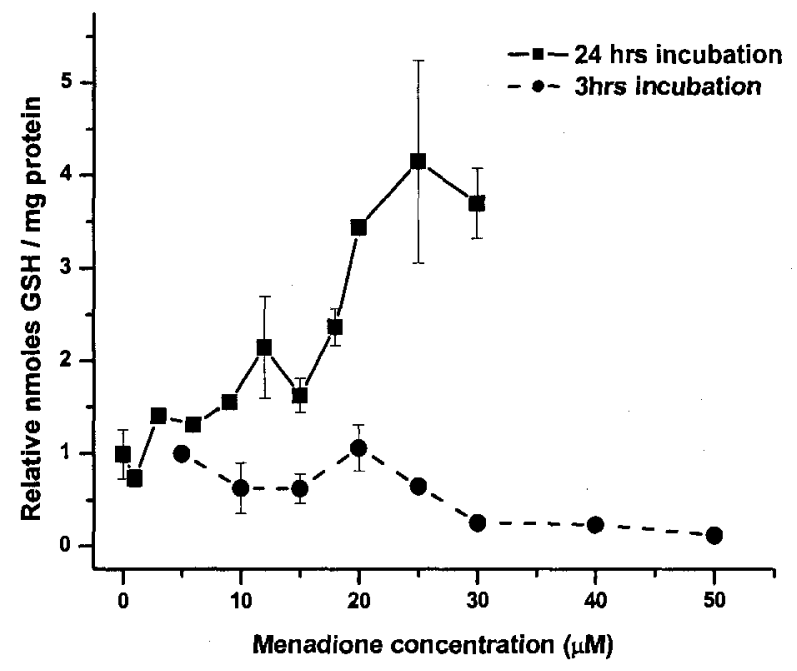

Figure 3.13. Total glutathione (GSH and GSSG) response curves as function of menadione concentration for 3 and 24 hours incubations at $37^{\circ} \mathrm{C}$. Total glutathione was normalized to $\mathrm{mg}$ protein in cell pellets. (Values represent means \pm S.E.M. $n=3$ ).

To verify the literature data, a short time incubation experiment of 3 hours was run. Once again our data support the proposed mechanism of total glutathione depletion for menadione toxicity. A steady and significant reduction in glutathione levels was measured. At concentrations higher than $30 \mu \mathrm{M}$ menadione, the intracellular pool of total glutathione was reduced to less than $25 \%$ of control values, with more cell death occurring at lower concentrations of glutathione. 


\section{Chapter 4}

\section{DISCUSSION}


Quinones exhibit their toxicity by one or both of two chemical processes: a stoichiometric process involving 1,4 addition reactions with thiols (glutathione) and a catalytic reduction of oxygen using quinone as a catalyst. The first mechanism, the Michael addition reaction, correlates with the reactivity of quinones as electrophiles in which nucleophilic groups ( $\mathrm{SH}$ for instance) in proteins or other molecules are alkylated (see chapter 1.2.1). This modified molecule would alter its normal functionality and initiate changes that can lead to cell death. The redox process generates superoxide ion that can induce oxidative damage to the cells. The major difference between the two mechanisms is that quinones play a catalytic role in the latter process. One equivalent of quinone can produce several equivalents of superoxide, thus overwhelming the antioxidant systems of the cell. Therefore is it important to study and understand the mechanism or mechanisms of toxicity for a particular compound and, if possible, to try to alter its properties and chemical structure in order to minimize the toxicity.

\subsection{Cytotoxicity - with and without catalase}

By comparing the $\mathrm{EC}_{50}$ values for the tested 1,2-diols (H1-DA, H2-DA, H4-DA and DPND-DA), as determined from the toxicity curves in Figures 3.1, 3.2, 3.3. and 3.4 respectively (see Table 2.1.), the following rank of toxicity can be established (moving from the most to the least toxic): H4-DA $\left(\mathrm{EC}_{50}=\right.$ $30 \mu \mathrm{M})>\mathrm{H} 2-\mathrm{DA}\left(\mathrm{EC}_{50}=53 \mu \mathrm{M}\right)>\mathrm{H} 1-\mathrm{DA}\left(\mathrm{EC}_{50}=116 \mu \mathrm{M}\right)>\mathrm{DPND}-\mathrm{DA}\left(\mathrm{EC}_{50}=\right.$ $157 \mu \mathrm{M})$. When analyzing the data obtained for the 1,4-diols, the order of most to least toxic is: Menadiol $\left(\mathrm{EC}_{50}=17.5 \mu \mathrm{M}\right)>$ Menadione $\left(\mathrm{EC}_{50}=21 \mu \mathrm{M}\right)>$ Menadiol-DA $\left(\mathrm{EC}_{50}=28 \mu \mathrm{M}\right)$. From these data alone, the tested compounds 
can be grouped in three different classes: 1,4-naphthalenediols and derivatives - extremely toxic, 1,2-catechols ( $H 1, H 2$ and $H 4)$ - toxic and 2,3naphthalenediol (DPND) - weak to virtually non-toxic.

When compounds H1-DA, H2-DA and H4-DA were tested for their cytotoxicity in the presence of $1000 \mathrm{U} / \mathrm{mL}$ catalase, a very dramatic result was obtained. As shown on Figures 3.1, 3.2 and 3.3, testing the toxicity of each compound at concentrations up to twice the obtained $\mathrm{EC}_{50}$ values in the absence of catalase produced toxicity curves that show very little if any loss in cell viability when compared to the controls. The fact that under catalase cotreatment, no $\mathrm{EC}_{50}$ values were able to be measured suggest beyond any doubt that extracellular hydrogen peroxide production is a major factor in the mechanism of catechol toxicity.

In comparison to the above results, when DPND-DA was incubated with $\mathrm{PC} 12 \mathrm{AC}$ in the presence of catalase, a small increase in cell viability was seen, possibly due to cell growth. Testing for viability with DPND-DA (0$200 \mu \mathrm{M})$, in both the presence and absence of catalase, resulted in an increase in $\mathrm{EC}_{50}$ value from $157 \mu \mathrm{M}$ (without catalase) to $200 \mu \mathrm{M}$ (with catalase) (Figure 3.4). Therefore extracellular hydrogen peroxide was less important in the cytotoxicity mechanism of 1,2-naphthalenediols.

In the case of 1,4-naphthalenediol derivatives (menadiol-DA, menadiol and menadione), the presence of catalase in the culture media had a relatively small effect on the cytotoxicity. While for Menadiol-DA (Figure 3.9) an increase of the $\mathrm{EC}_{50}$ values, from 28 to $37 \mu \mathrm{M}$, was observed, for menadiol (Figure 3.10) the increase is less significant, reaching $214 \%$. The explanation resides in the fact that, of the diols, menadiol can autoxidize easily in the 
extracellular space before diffusing inside the cells. In contrast, once diacetylated, the autoxidation of menadiol is no longer possible.

Menadione, with an increase from 21 to $33.5 \mu \mathrm{M}$ in $\mathrm{EC}_{50}$ values $(160 \%$ compared to untreated controls; Figure 3.11), is situated in-between the $\mathrm{OH}$ free and acetylated form of its parent diol (in terms of change in $\mathrm{EC}_{50}$ values when treated with catalase compared to control experiments). This observation can be explained by taking into account that the quinone can be reduced to its parent, in this case menadione, and that it's not as inert as the menadiol-DA. Moreover, this fact is confirmed by the ranking in cytotoxicity for the tests in the absence of catalase.

Overall, we can conclude that hydrogen peroxide plays a much more important role in the cytotoxicity of 1,2-diols (H1-DA, H2-DA and H4-DA) than for naphthalenediols (1,2-DPND-DA and 1,4-Menadiol-DA).

\subsection{Correlation between cytotoxicity and intracellular GSH levels}

For all the compounds tested, the most common cellular response was the up-regulation of the intracellular total glutathione levels after 24 hrs of incubation. The magnitude of the increase in glutathione varied from approximately two-fold for menadiol (Figure 3.12) and H1-DA (Figure 3.8) after $24 \mathrm{~h}$ to almost four-fold for menadione (Figure 3.13) and H2-DA (Figure 3.8).

Since the range of concentrations used for the glutathione assay was chosen based on the $\mathrm{EC}_{50}$ values specific for each compound, it was more appropriate to compare the slope of the glutathione response curves (rate of production) than the maximum level of intracellular glutathione reached, 
relative to the control cells. When analyzing the rates of glutathione upregulation, $\mathrm{H} 2-\mathrm{DA}$ and $\mathrm{H} 4-\mathrm{DA}$ proved to induce the fastest increase in the intracellular glutathione content, followed by H1-DA. DPND-DA exhibited no increase in intracellular glutathione up to concentrations of $100 \mu \mathrm{M}$. Above this concentration, the cellular levels of glutathione increased with increasing DPND-DA.

The order in which compounds upregulated glutathione was H2-DA $\approx$ H4-DA > H1-DA >> DPND-DA which correlated very closely to compound ranking in cytotoxicity (H4-DA > H2-DA > H1-DA > DPND-DA).

As discussed in the "Introduction" chapter, ROS generated by phenols and other xenobiotics induce an up-regulation of the intracellular glutathione. By analyzing the chemical structures of the tested catechols, it is notable that H4-DA is the only compound that can take part in the Michael addition reactions. This could cause a decline in the glutathione levels in PC12-AC cells by alkylation. This mechanism alone contradicts though the observation that H4-DA induces an overall increase in the intracellular GSH levels (Figure 3.8). The conclusion would be that under oxidative stress induced by the tested catechols and naphthalenediols the cells are responding by increasing the amount of reduced GSH available to counteract the damage induced by the ROS. Since it was the total GSH levels that were measured it cannot be concluded definitively what mechanisms the cells are using to produce GSH are. 


\subsection{Cytotoxicity is correlated with hydrogen peroxide generation}

Since added catalase had a large impact on the cytotoxicity of H1-DA (Figure 3.1), H2-DA (Figure 3.2) and H4-DA (Figure 3.3) it is reasonable to conclude that, overall, hydrogen peroxide plays an important role in the toxicity of catechols.

When measuring the accumulation of hydrogen peroxide in the culture media of treated cells (Figure 3.5), the initial rate of hydrogen peroxide generation follows exactly the ranking order of cytotoxicity: H4-DA > H2-DA > H1-DA.

A parallel indicator of the oxidation process involves the quantification of the quinone product. The quinone product is produced when the parent compound enters the cell, becomes hydrolyzed and then oxidized. Oxidation may occur either inside the cell or extracellularly after transport of the hydrolyzed product to the outside the cell.

As shown on Figure 3.7, the observed ranking for quinone production is $\mathrm{H} 4-\mathrm{DA}>\mathrm{H} 2-\mathrm{DA}>\mathrm{H} 1-\mathrm{DA}$. As expected, this order correlates with hydrogen peroxide production and cytotoxicity of the compounds.

In order to determine which step of the catechol's cytotoxicity mechanism (as described above) had the highest contribution to loss of cell viability, we attempted to quantify the autoxidation process. The time-course of hydrogen peroxide production, resulting from autoxidation of the four tested catechols (in their free $\mathrm{OH}$ form) in HBSS, is shown in Figure 3.6. Hydrogen peroxide was produced as early as 5 minutes (the first time point recorded) after the addition of catechols, at which the maximum level for both $\mathrm{H} 2$ and H4 was reached. It can be concluded that autooxidation occurred very rapidly. 
$\mathrm{H} 1$ produced hydrogen peroxide at a much slower rate, reaching a maximum within 25 minutes of incubation with compound. For DPND, it was noted that the maximum level of hydrogen peroxide attained was half of that of the other diols. This correlated with cytotoxicity, as represented by $\mathrm{EC}_{50}$ values $(\mathrm{H} 4>$ $\mathrm{H} 2>\mathrm{H} 1>\mathrm{DPND})$.

The process of autooxidation occurs with the following sequence of events: 1) cellular uptake of the diol (diffusion of the DA form of the diol into the cell), 2) hydrolysis of the acetyl groups to free the parent diol, 3) efflux of the deacetylated product from the cell and 4) autoxidation of the product in the extracellular space.

If the autooxidation would occur inside the cells then quinones and hydrogen peroxide would be produced intracellularly. To protect itself against the toxic effects of the quinones, as part of phase II metabolism, GSH adducts with the quinones would form and quickly being transported outside the cells. This would induce an overall loss of glutathione that contradicts the upregulation observed. Also the hydrogen peroxide produced intracellularly would start damaging the cells from inside, again contradicting the observed significant effect of reducing the cytotoxicity of the tested compounds when extracellular catalase was added. In the case of DPND-DA which cannot easily autoxidize we can see that extracellular catalase has very little effect. It is also be possible that the intracellular catalase would decompose the hydrogen peroxide produced by intracellular autoxidation rendering autooxidized products harmless.

As discussed by Brunmark (1988) addition of glutathione to quinones showed an extremely fast loss of quinone specific absorbance peak and 
appearance of two new peaks characteristic for the glutathionylderivatives. The fact that we were able to spectrophotometrically measure extracellular quinone levels (in the case of H4-DA account for $100 \%$ of the autoxidation product - Figure 3.7) supports the idea that the autoxidation process occurs mainly in the extracellular space.

By quantifying the hydrogen peroxide present in the medium (Figure 3.5) and the accumulation of the quinone in the extracellular environment (Figure 3.7) the overall rate of autooxidation could be measured. Since $\mathrm{H} 2$, $\mathrm{H} 4$, and $\mathrm{H} 1$ autooxidized rapidly, the dramatic difference between hydrogen peroxide production and quinone production (Figure 3.7 ) can be explained in that either the uptake of the diol or the efflux of the deacetylated product is rate-limiting. For instance, $\mathrm{H} 4$ and $\mathrm{H} 2$ are autooxidizing equally fast but $\mathrm{H} 2-$ DA is twice as slow as H4-DA at quinone accumulation in the medium. This observation supports the conclusion that $\mathrm{H} 2$ is slower than $\mathrm{H} 4$ in crossing the membrane in both its DA form (into the cells) as well as its $\mathrm{OH}$ free form (outside the cell).

Several parallel observations (the fast autoxidation of the catechols in the medium (Figure 3.6), the detection of the oxidation products (quinone) in the extracellular space (Figure 3.7) and dramatic decrease in the cytotoxicity upon addition of catalase (Figures $3.1,3.2$ and 3.3 )) lead to the general conclusion that extracellular autoxidation of the catechols is a major mechanism through which these compounds manifest their toxic effects.

The rate at which the compounds are metabolized (uptake, hydrolysis and efflux) is controlled, ultimately, by the cell. Since uptake and efflux are the 
rate limiting steps, the faster the rate of compound processing, the faster the rate of extracellular autooxidation and (eventually) cell death.

DPND had a character that differed from both catechols and menadiol. The lack of effect of catalase on DPND cytotoxicity separated it from the catechols. The low toxicity of DPND compared to the other naphthalenediol tested (menadiol) makes it favourable for a potential therapeutic antioxidant. The chemical nature of DPND reveals the reason for the difference in toxicity. 1,2- (Figure 4.1) and 1,4-naphthalenediol (Figure 4.2) easily form stable semiquinones and quinones.<smiles>O=C1C=Cc2ccccc2C1=O</smiles>

Figure 4.1. Dihydroxy, semiquinone and quinone forms of 1,2naphthalenediol.<smiles>Oc1ccc(O)c2ccccc12</smiles><smiles>[O-]c1ccc(O)c2ccccc12</smiles><smiles>O=C1C=CC(=O)c2ccccc21</smiles>

Figure 4.2. Dihydroxy, semiquinone and quinone forms of 1,4naphthalenediol.

Compounds with structures related to 2,3-naphthalenediols (DPND included) easily form semiquinones. The quinone formation, however, 
requires the loss of aromaticity not only in the $\mathrm{OH}$-bearing ring but also in the adjacent ring as well (Figure 4.3). We estimate that this loss in aromaticity comes with an energy "price" of approximately $10 \mathrm{kcal} / \mathrm{mol}$ (Chichirau, 2005).<smiles>Cc1cc2c(C)cccc2cc1O</smiles>

Figure 4.3. Dihydroxy, semiquinone and quinone forms of 2,3naphthalenediol

It can be concluded then that the rate of autooxidation of the catechol correlates very well with the cytotoxicity: 1) the extremely fast autoxidative compounds ( $\mathrm{H} 4$ and $\mathrm{H} 2$ ) showing the lowest $\mathrm{EC}_{50}$ values, 2) $\mathrm{H} 1$ situated somewhere in the middle and 3) DPND having very slow (if any) autooxidation and being the least toxic of all the catechols. We have to add to this conclusion the fact that catalase has an overall effect of drastically reducing the cellular toxicity. The hydrogen peroxide production correlated with the quinone chromophore accumulation in the extracellular space. All these general observations lead to the overall mechanism of $\mathrm{H} 1, \mathrm{H} 2$ and $\mathrm{H} 4$ toxicity which consist of five steps: 1) transport of the DA form of the tested compounds into the cells, 2) deacetylation to catecholic form, 3) efflux of the catecholic form to the extracellular space, 4) autooxidation to produce hydrogen peroxide with the formation of quinone and 5) cell damage resulting in loss of viability. 
In the case of naphthalenediols (DPND and menadiol), catalase did not have significant effects on toxicity reduction, suggesting that overall redox cycling plays a less important role than in the case of catechols. With the catechols, glutathione depletion led to a loss in cell viability. Long-term treatments $(24 \mathrm{hrs})$ with menadiol/menadione were initially conducted; the results showing an increase in the intracellular levels of glutathione. Glutathione depletion by menadione was confirmed when short time ( $3 \mathrm{hrs}$ ) incubation experiments were performed. The two time points clarified the mechanism of menadione's toxicity. Intracellularly menadione nucleophylically reacts with glutathione (Talamoni, 2005). When intracellular levels of glutathione are low, cells respond by up-regulating glutathione synthesis and this was observed when cells were treated for an acute exposure at low concentrations of menadione. Upon chronic exposure to higher concentrations of menadione, an overall loss in the GSH levels was observed. Ultimately, cells can no longer maintain reduced thiol concentrations and cell death ensues. Being part of the naphthalenediol family, DPND is expected to have similar effects. Even though eventually a rise in the intracellular glutathione level was measured with DPND treatment, blocking the 1,4 position with large dipropyl moieties reduced the reactivity of DPND towards thiols. Since the structure of DPND does not allow for an easy and fast autooxidation (this requires the loss of aromaticity in the second ring as well as unobstructed positions at 1 and 4 ), the question of the mechanism of the DPND toxicity remains. It can only be proposed that with the help of the lipophylic anchors provided by the propyl substituents, DPND preferentially locates itself in the cell membrane where it can induce lipid peroxidation by 
HAT. The cells will detect the oxidative damage and will respond by upregulating glutathione synthesis.

From the results, it can be concluded that, in order to avoid or at least minimize the pro-oxidant effect linked to catechols and diols in general, a good candidate for potent antioxidant with reduced cytotoxicity should possess such a structure that limits the possibility of autoxidation. As exemplified with DPND, the requirements would be to choose compounds that can easily form semiquinones, thus allowing them to quickly act as antioxidants by HAT to a radical (lipid peroxyl radical for instance) but have high activation energies for the formation of quinones (i.e. loss of aromaticity of more then one cycle). Since the presence of quinone is the requirement for autoxidation and redox cycling, the new formula should avoid or reduce the chances of the quinone being formed. In order to lessen the occurance of cytotoxicity by formation of adducts with biological molecules (thiols or DNA bases), complete blockage of the positions adjacent to the hydroxy substituents could be applied. By choosing the right substituents, the hydrophillicity/lipophillicity of the new compounds can be tuned so that they would distribute preferentially in the desired cellular location (i.e. membrane vrs. the cytosol).

These observations open the door for the possible usage of naphthalenediols $(2,3$ or 1,8$)$ that do not easily form quinones in antioxidant formulations, for therapeutic applications.

In order to support the prospect of therapeutic use, more testing is required. This should include the study of toxicity and antioxidant effects on different cell types, the study of the exact mechanism of cytotoxicity, and the 
study of how alteration of the structure (substituents) of naphthalenediols alters their antioxidant activity while minimizing their pro-oxidant action. 
REFERENCES 
Ault J.G., Lawrence D.A., 2003 - Glutathione distribution in normal and oxidatively stressed cells, Experimental Cell Research, vol. 285, 9-14

Benov L., 2001 - How superoxide radical damages the cell, Protoplasma, vol. 217, 33-36

Bergmann, B., Dohrmann, J. K., Kahl, R., 1992 - Formation of the semiquinone anion radical from tert-butylquinone and from tert-butylhydroquinone in rat liver microsomes, Toxicology, vol. 74, 127-33

Bharath S., Cochran B.C., Hsu M., Liu J., Ames B.N., Andersen J.K., 2002 - Pretreatment with R-lipoic acid alleviates the effects of GSH depletion in PC12 cells: implications for Parkinson's disease therapy, NeuroToxicology, vol. 23, $479-486$

Boots A.W., Haenen G.R.M.M., Den Hartog G.J.M., Bast A, 2002 - Oxidative damage shifts from lipid peroxidation to thiol arylation by catechol-containing antioxidnts, Biochimica et Biophysica Acta, vol. 1583, 279-284

Boots A.W., Bast A., Haenen G.R.M.M., 2005 - No role of DT-diaphorase (NQO1) in the protection against oxidized quercetin, FEBS Ketters, vol. 579, 677-682

Bradford, M.M., 1976 - A rapid and sensitive method for the quantitation of microgram quantities of protein utilizing the principle of protein-dye binding, Analytical Biochemistry, vol. $72,248-254$ 
Bravo L., 1998 - Polyphenols: chemistry, dietary sources, metabolism and nutritional significance, Nutrition Reviews, vol. 56, 317-333

Brighente I.M.C., Dias M., Verdi L.G., Pizzolatti M.G, 2007 - Antioxidant activity and total phenolic content of some Brazilian species, Pharmaceutical Biology, vol $45,156-161$

Brunmark A., Cadenas E., 1988 - Reductive addition of glutathione to pbenzoquinone, 2-hydroxy-p-benzoquinone and p-benzoquinone epoxides. Effects of the hydroxy- and glutathionyl substituents on p-benzoquinone autoxidation, Chemico-Biological interactions, vol. 68, 273-298

Bukowska B., Kowalska S. - Phenol and catechol induce prehemolytic and hemolytic changes in human erythrocytes, Toxicology Letters, vol. 152, 2004, 73-84

Cadenas E., 1995 - Antioxidant and prooxidant functions of DT-diaphorase in quinone metabolism, Biochemical Pharmacology, vol. 49, 127-40

Cao G., Sofic E., Prior R.L., 1997 - Antioxidant and prooxidant behavior of flavonoids: structure-activity relationships, Free Radical Biology and Medicine, vol. $22,749-760$ 
Cavalieri E.L., Stack D.E., Devanesan P.D., 1997 - Molecular origin of cancer: Catechol estrogen-3,4-quinones as endogenous tumor initiators, Proceedings of the Natural Academy of Science of USA, vol. 94, 10937-10942

Cavalieri E.L., Li Kai-Ming, Balu N., Saeed M., Devanesan P., Higginbotham S., Zhao J., Gross M.L., Rogan E.G., 2002 - Catechol ortho-quinones: the electrophilic compounds that form depurinating DNA adducts and could initiate cancer and other diseases, Carcinogenesis, vol. 23, 1071-1077

Chang M., Shi M., Forman H.J., 1992 - Exogenous glutathione protects endothelial cells from menadione toxicity, American Journal of Physiology, vol. $262,637-643$

Chichirau A, Flueraru M, Chelepev L.L., Wright J.S., Willmore W.G., Durst T., Hussain H.H., Charron M., 2005 - Mechanism of cytotoxicity of catechols and a naphthalenediol in PC12-AC cells: the connection between extracellular autoxidation and molecular electronic structure, Free Radical Biology and Medicine, vol. 38, 344-355

Chung Jin-Ho, Seo Dong-Chul, Chung Sun-Hwa, Lee Joo-Young, Seung SangAe, 1997 - Metabolism and cytotoxicity of menadione and its metabolite in rat platelets, Toxicology and Applied Pharmacology, vol. 142, 378-385 
De Lange, D. W., 2007 - From red wine to polyphenols and back: A journey through the history of the French Paradox, Thrombosis Research, vol. 119, 403-406

Dickinson D.A., Forman H.J., 2002 - Glutathione in defense and signaling: lessons from a small thiol, Annals of the New York Academy of Science, vol. $1973,488-504$

Dickinson D.A., Moellering D.R., lles K.E., Patel R.P., Levonen A.L., Wigley A., Darley-Usmar V.M., Forman H.J., 2003 - Cytoprotection against oxidative stress and the regulation of glutathione synthesis, Biological Chemistry, vol. $384,527-537$

Eftekhar E., Arne H., Bernhard H.JJ., 2000- Thioredoxin reductase and glutathione synthesis is upregulated by t-butylhydroquinone in cortical astrocytes but not in cortical neurons, Glia, vol. 31, 241-248

El Habit O.H., Saada H.N., Azab K.S., 2000 - The modofying effect of betacarotene on gamma radiation -induced elevation of oxidative reactions and genetoxicity in male rats, Mutation Research, vol. 466, 179-186

Filomeni G., Rotilio G., Ciriolo M.R., 2002 - Cell signalling and the glutathione redox system, Biochemical Pharmacology, vol. 64, 1057-1064 
Fraga C.G., 2007 - Plant polyphenols: How to translate their in vitro antioxidant actions to in vivo conditions, IUBMB Life, vol. 59, 308-315

Furusawa M., Tanaka T., Ito T., 2005 - Antioxidant activities of hydroxyl flavonoids, Journal of Health Science, vol. 51, 376-378

Galati G., O'Brien P.J., 2004 - Potential toxicity of flavonoids and other dietary phenolics: Significance for their chemopreventive and anticancer properties, Free Radical Biology and Medicine, vol. 37, 287-303

Gant T.W., Ramakrishna R.D.N., Mason R.P., Cohen G.M., 1988 - Redox cycling and sulphydryl arylation: their relative importance in the mechanism of quinone cytotoxicity to isolated hepatocytes, Chemico-Biological Interactions, vol. $65,157-173$

Gant T.W., Rao D.N., Mason R.P., Cohen G.M., 1988 - Redox cycling and sulphydryl arylation their relative importance in the mechanism of quinone cytotoxicity to isolated hepatocytes, Chemico- Biological Interaction, vol. 65, $157-73$

Halliwell B., Gutteridge J.M.C., Cross C.E., 1992 - Free radicals antioxidants and human disease: Where are we now?, Journal of Laboratory and Clinical Medicine, vol. 119, 598-620 
Han D., Handelman G., Marcoci L., Sen C.K., Roy S., Kobucki H., Tritschler H.J., Flohe L., Packer L., 1997 - Lipoic acid increases de novo synthesis of cellular glutathione by improving cystine utilization, Biofactors, vol. $6,321-338$

Han Shan-Kuo, Mytilineou C., Cohen G., 1995 - L-DOPA up-regulates glutathione and protects mesencephalic cultures against oxidative stress, Journal of Neurochemistry, vol. 66, 501-51

Harborne J.B., Baxter H., Miss G.P., 1999 - Phytochemical dictionary: Handbook of bioactive compounds from plants, Taylor \& Francis, London, UK

Heim K.E., Tagliaferro A.R., Bobilya D.J., 2002 - Flavonoid antioxidants: chemistry, metabolism and structure-activity relationships, The Journal of Nutritional Biochemistry, vol. 13, 572-584

Keijnen C.G.M., Haenen G.R.M.M., Oostveen R.M., Stalpers E.M., Bast A., 2002 - Protection of flavonoids against lipid peroxidation: the structure activity relationship revisited, Free Radical Research, vol. 36, 575-581

Higdon, Jane V., Frei B., 2003 - Tea catechins and polyphenols: health effects, metabolism, and antioxidant functions, Critical Reviews in Food Science and Nutrition, vol. $43,89-143$ 
Ishige K., Schubert D., Sagara Y., 2001 - Flavonoids protect neuronal cells from oxidative stress by three distinct mechanisms, Free Radical Biology and Medicine, vol. 30, 433-446

Kulys J., Tetianec L., 2006 - Highly sensitive biosensor for the hydrogen peroxide determination by enzymatic triggering and amplification, Sensors and Actuators B: Chemical, vol. 113, 755-759

Lee Joo-Young, Bae Ok-Nam, Chung Seung-Min, Lee Moo-Yeol, Chung Jin-Ho, 2001 - Menadione induces endothelial dysfunction mediated by oxidative stress and arylation, Chemico-Biological Interactions, vol. 137, 169-183

Levay G., Bodell W.J., 1992 - Potentiation of DNA adduct formation in HL-60 cells by combinations of benzene metabolites, Proceedings of the Natural Academy of Sciences of USA, vol. 89, 7105-7109

De Loecker W.; Janssens J.; Bonte J.; Taper H.S., 1993 - Effects of sodium ascorbate (vitamin C) and 2-methyl-1,4-naphthoquinone (vitamin $\mathrm{K}_{3}$ ) treatment on human tumor cell growth in vitro. II. Synergism with combined chemotherapy action. Anticancer Research, vol. 13, 103-6

Manach C., Williamson G., Morand C., Sclabert A., Remesy C., 2005 Bioavailability and bioefficacy of polyphenols in humans.I. Review of 97 bioavailability studies, American Journal of Clinical Nutrition, vol. 81, 230-242 
Martinez V.I., Periago M.J., Provan G., Chesson A., 2002 - Phenolic compounds, lycopene and antioxidant activity in commercial varieties of tomato, Journal of the Science of Food and Agriculture, vol. 82, 323-330

Matsuura T., Ohkatsu Y., 2000 - Phenolic antioxidants: effect of ortho-benzyl substituents, Polymer Degradation and Stability, vol. 70, 59-63

May J.M., Qu Zhi-chao, Li X., 2003 - Ascorbic acid blunts oxidative stress due to menadione in endothelial cells, Archives of Biochemistry and Biophysics, vol. $411,136-144$

McAmis W.C., Schaeffer Jr., Richard C., Baynes J.W., Wolf M.B., 2003 Menadione causes endothelial barrier failure by a direct effect on intracellular thiols, independent of reactive oxidant production, Biochimica et Biophysica Acta, vol. $1641,43-53$

Moridani M.y., Scobie H., O'Brien P.J., 2001 - Catechin metabolism: glutathione conjugate formation catalysed by tyrosinase, peroxidase and cytochrome P450, Chemical Research in Toxicology, vol. 14, 841-848

Moridani M.Y., Siraki A., O'Brien P.J., 2003 - Quantitative structure toxicity relationship for phenol in isolated rat hepatocytes, Chemico-Biological Interactions, vol. 145, 213-223 
Morton L.W., Caccetta R.A-A., Puddey I.B., Croft K.D., 2000 - Chemistry and biological effects of dietary phenolic compounds: relevance to cardiovascular disease, Clinical and Experimental Pharmacology and Physiology, vol. 27, $152-159$

Mytilineou C.; Kramer B.C; Yabut J.A., 2002 - Glutathione depletion and oxidative stress, Parkinsonism \& Related Disorders, vol. 8, 385-7

Parr A.J., Bolwell G.P., 2000 - Phenols in the plant and in man. The potential for possible nutritional enhancement of the diet by modifying the phenols content or profile, Journal of the Science of Food and Agriculture, vol. 80, 985-1012

Pethig R., Gascoyne P.R., McLaughlin J.A., Szent-Gyorgyi A., 1983 - Ascorbatequinones interactions: Electrochemical free radical and cytotoxic properties, Proceedings of the Natural Academy of Sciences of USA, vol. 80, 129-32

Powis G., Appel P.L., 1980 - Relationship of the single-electron reduction potential of quinones to their reduction by flavoproteins, Biochemical Pharmacology, vol. 29, 2567-72

Pryor W.A., Stone K., Zang L-Y., Benmudez E., 1998 - Fractionation of aqueous cigarette tar extracts: fractions that contain the tar radical cause DNA damage, Chemical Research in Toxicology, vol. 11, 441-448 
Puupponen Pimaja R., Nohynek L., Meier C., Kahkonen M., Heinonen M., Kopia A., 2001 - Antimicrobial properties of phenolic compounds from berries, Journal of Applied Microbiology, vol. 90, 494-507

Rive-Evans C.A., Miller N.J., Pagange G., 1997 - Antioxidant properties of phenolic compounds, Trends in Plant Science, vol. 2, 152-159

Ross D., 1996 - Metabolic basis of benzene toxicity, European Journal of Haematology, vol. 57, 111-118

Rossi L., Moore S., Orrenius S., O'Brien P.J., 1986 - Quinone toxicity in hepatocytes without oxidative stress, Archives of Biochemistry and Biophysics, vol. 251, 25-35

Said Ahmad M., Fazal F., Rahman A., Hadi S.M., Parish J.H., 1992 - Activities of flavonoids for the cleavage of DNA in the presence of $\mathrm{Cu}(\mathrm{II})$ : correlation with generation of active oxygen species, Carcinogenesis, vol. 13, 605-608

Schlosser P.M., Bond J.A., Medinsky M.A., 1993 - Benzene and phenol metabolism by mouse and rat liver microsomes, Carcinogenesis, Vol 14, $2477-2486$

Schweigert N., Zehnder A. J.B., Eggen R.I.L., 2001 - Chemical properties of catechols and their molecular modes of toxic action in cells, from microorganisms to mammals, Environmental Microbiology, vol. 3, 81-91 
Syrus R. S., Konjetic R.S., Meredith M.J., Freeman M.L., 2000- Multi-faceted regulation of $\gamma$-glutamylcysteine synthetase, Journal of Cellular Physiology, vol. $182,163-170$

Talamoni, NT., Marchionatti A., de Barboza G.D., Perez, A., 2005 - Cellular and biochemical alterations caused by artificial depletion of glutathione, Current Enzyme Inhibition, vol. 1, 123-130

Tampo Y., Yonaha M., 1996 - Enzymatic and molecular aspects of the antioxidant effect of menadione in hepatic microsomes, Archives of Biochemistry and Biophysics, vol. 334, 163-174

Tapper M.A., Sheedy B.R., Hammermeister D.E., Schmieder P.K., 2000 Depletion of cellular protein thiols as an indication of arylation in isolated trout hepatocytes exposed to 1,4-benzoquinone, Toxicological Sciences, vol. 55, $327-43$

Thor H., Smith M.T., Hartzell P., Bellomo G., Jewell S.A., Orrenius S., 1982 - The metabolism of menadione (2-methyl-1,4-naphthoquinone) by isolated hepatocytes, The Journal of Biological Chemistry, vol. 257, 12419-12425

Tietze, F., 1969 - Enzymatic method for quantitative determination of nanogram amounts of total and oxidized glutathione: Applications to mammalian blood and other tissues. Analytical Biochemistry, vol. 27, 502-522 
Tsao C.W., Song H.G., Dagger R.B., 1998 - Metabolism of benzene, toluene, and xylene hydrocarbons in soildagger, Applied and Environmental Microbiology, vol. 64,4924 - 4929

Wanasundara U.N., Shahidi F., 1998 - Antioxidant and prooxidant activity of green tea extracts in marine oils, Food Chemistry, vol. $63,335-342$

Wang L, Tu Y.C., Lian T.W., Hung J.T., Yen J.H., Wu M.J., 2006 - Distinctive antioxidant and antiinflammatory effects of flavonols, Journal of Agricultural and Food Chemistry, vol. 54, 9798-9804

Watanabe N., Forman H.J., 2003 - Autoxidation of extracellular hydroquinones is a causative event for the cytotoxicity of menadione and DMNQ in A 549-S cells, Archives of Biochemistry and Biophysics, vol. 411, 145-157

Woods J.S, Kavanagh T.J, Corral J., Reese A.W., Diaz D., Ellis M.E., 1999 - The role of glutathione in chronic adaptation to oxidative stress: studies in a normal rat kidney epithelial (NRK52E) cell model of sustained upregulation of glutathione biosynthesis, Toxicology and Applied Pharmacology, vol. 160, 207-216 